\title{
Hydrogen and VOC Retention in Waste Boxes
}

Prepared for the U.S. Department of Energy

Assistant Secretary for Environmental Management

Project Hanford Management Contractor for the

U.S. Department of Energy under Contract DE-AC06-96RL13200

\section{FLUOR}

P.O. Box 1000

Richland, Washington

\section{Approved for Public Release; Further Dissemination Unlimited}


HNF-22524

Revision 1

EDC \#: HNF-EDC-08-38014

\section{Hydrogen and VOC Retention in Waste Boxes}

R. M. Marusich

Fluor Government Group

Date Published

June 2008

Prepared for the U.S. Department of Energy

Assistant Secretary for Environmental Management

Project Hanford Management Contractor for the

U.S. Department of Energy under Contract DE-AC06-96RL13200

FLUOR

P.O. Box 1000

Richland, Washington

$\frac{\text { Nancy A. Fonad }}{\text { Release Approval }} \frac{11-21-08}{\text { Date }}$

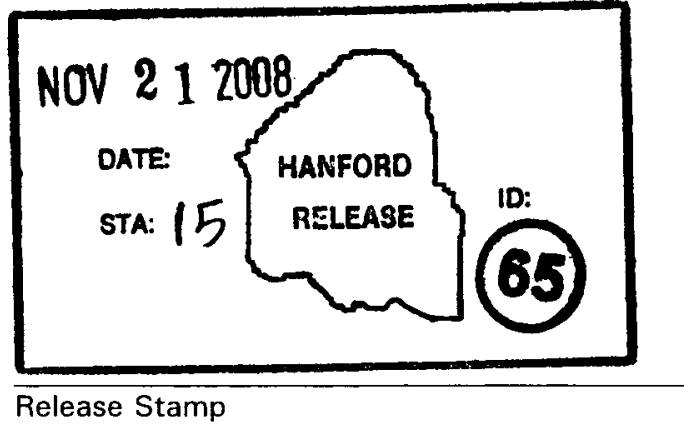

Approved for Public Release;

Further Dissemination Unlimited 
HNF-22524

Revision 1

TRADEMARK DISCLAIMER

Reference herein to any specific commercial product, process, or service by trade name, trademark, manufacturer, or

otherwise, does not necessarily constitute or imply its

endorsement, recommendation, or favoring by the United

States Government or any agency thereof or its contractors or subcontractors.

This report has been reproduced from the best available copy.

Printed in the United States of America

Toatl pags: 67 


\section{RECORD OF REVISION}

(2) Title

Hydrogen and VOC Retention in Waste Boxes
(1) Document Number

$\mathrm{HNF}-22524$

Change Control Record

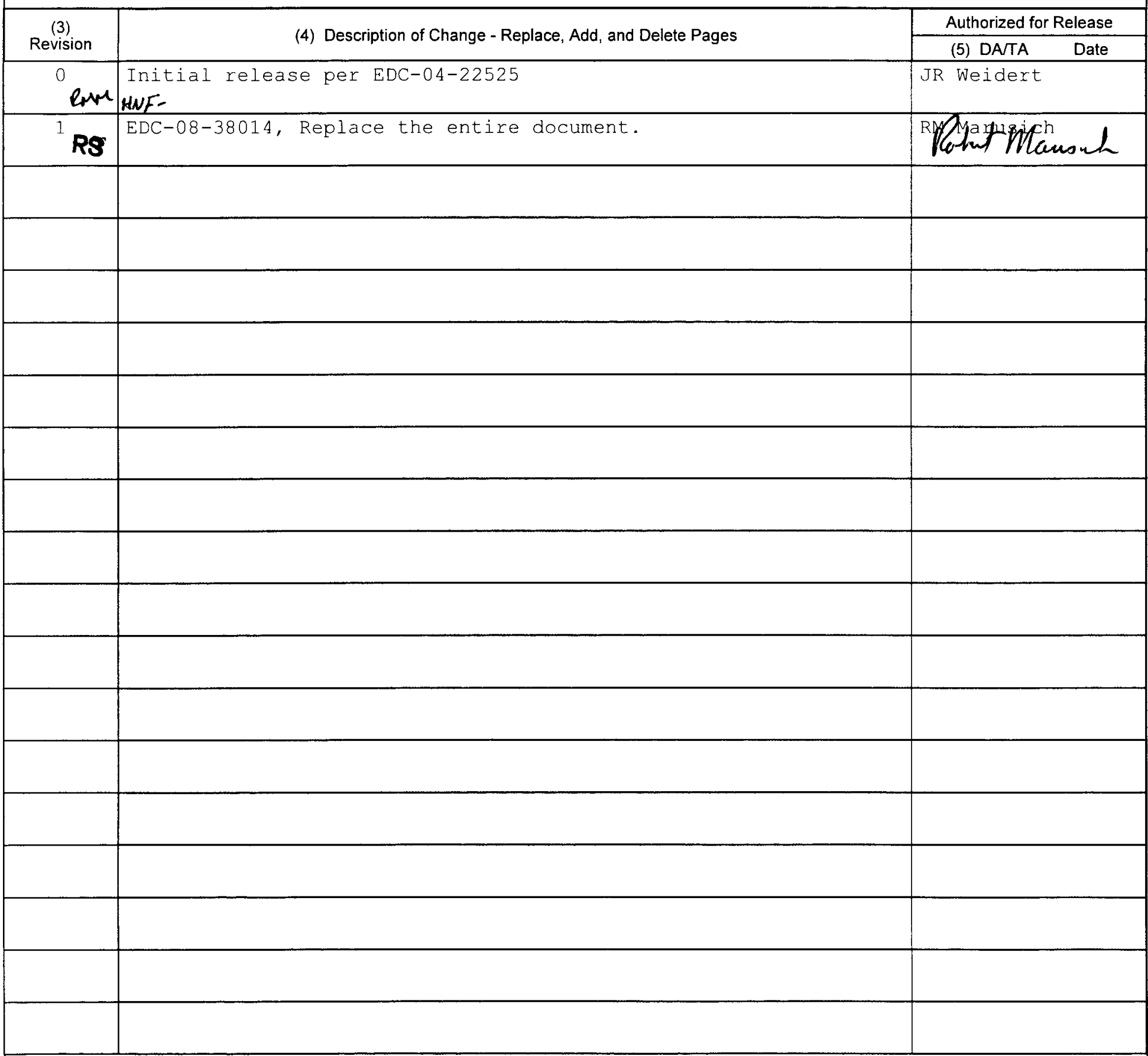


HNF-22524, Rev. 1

\section{Hydrogen and VOC Retention in Waste Boxes}


HNF-22524, Rev. 1

This page is intentionally left blank. 


\section{TABLE OF CONTENTS}

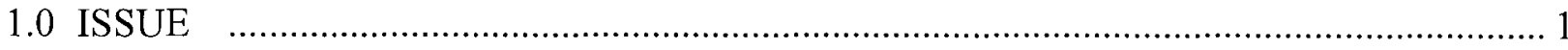

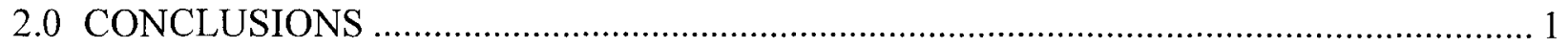

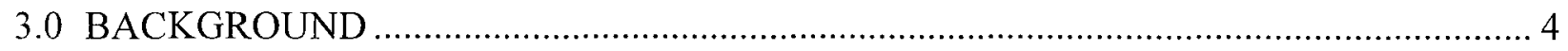

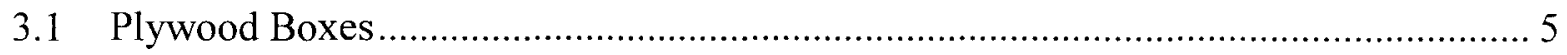

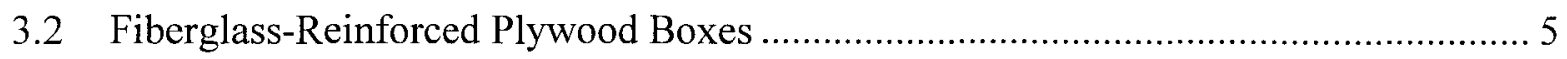

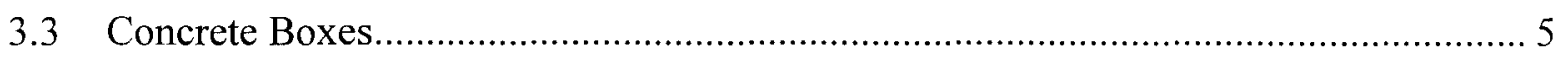

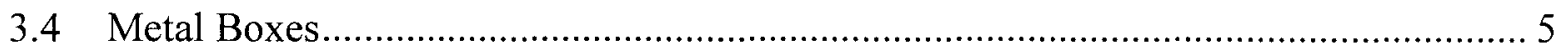

4.0 ANALYSIS OF HYDROGEN AND VOLATILE ORGANIC CARBON (VOC)

VAPOR RETENTION IN TRU WASTE BOXES ................................................. 7

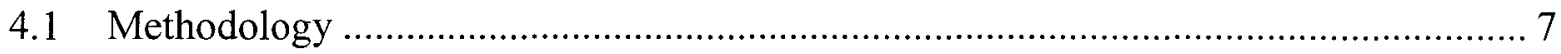

4.2 The Potential for Hydrogen Accumulation .......................................................... 7

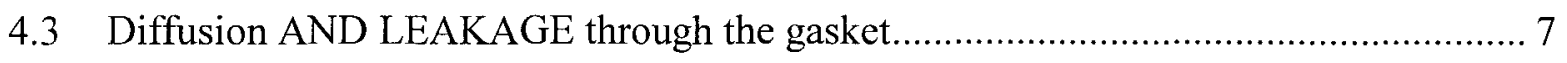

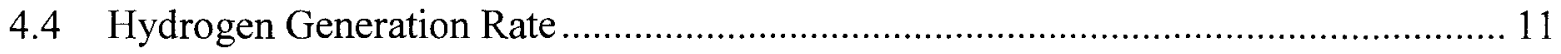

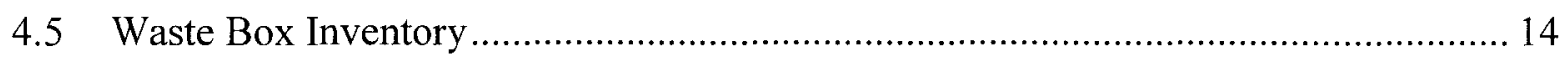

4.6 Fraction of the Inventory that Affects the Waste .................................................... 14

4.7 Diffusion and Leakage Spreadsheet for a pressurized waste box …........................... 14

4.7.1 Diffusion and Leakage of Hydrogen in Pressurized Waste Boxes ................. 15

4.7.2 Lid Deflection ........................................................................................ 21

4.8 Leakage and Diffusion out a Non-Pressurized Waste Box ……................................. 22

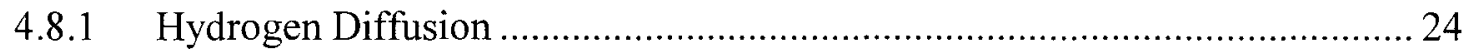

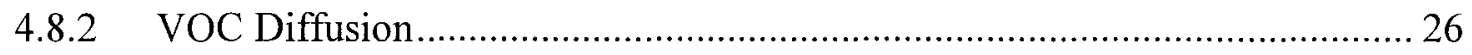

4.8.2.1 VOC Concentration After 40 Years of Burial (Prior to

Retrieval) ............................................................................... 27

4.8.2.2 VOC Concentration After Retrieval Following Burial ........................ 31

4.8.2.3 VOC Concentration With No Burial................................................... 33

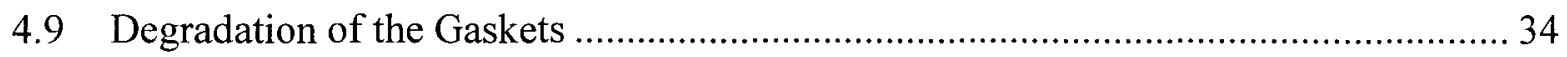

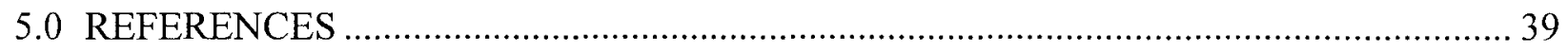

APPENDIX A - LISTING OF THE WASTE BOXES ……................................................ A-1

APPENDIX B - THE EFFECT OF A HYDROGEN

DEFLAGRATION ON THE WASTE BOX ………….................................... B-1

APPENDIX C - TECHNICAL PEER REVIEW SHEET ...................................................... C-1 


\section{LIST OF TABLES}

Table 1. Unique Safety Controls for Single Container Deflagration

Table 2a. Permeability of Various Gases in Various Rubbers at 23C-25C (Notes 1,2)

Table 2b. Permeability of Hydrogen Through Various Kinds of Rubber Data from Permeability Properties

Table 2c. Permeability of Hydrogen Through Various Kinds of Rubber Data From Polymer Handbook

Table 3. Experimental Dose-Dependent G Values

Table 4. Gas Yields ( $\mathrm{cm}^{3} /$ day-Ci) for use in Risk Assessments for Plutonium-Contaminated Material

Table 5. Hydrogen Concentration From 50 DE-Ci From Alpha Emitters

Table 6. Hydrogen Concentration From 26 DE-Ci From Alpha Emitters

Table 7. Hydrogen Concentration - Miscellaneous Cases that Result in a Hydrogen

Concentration of $4 \%$ or Less

Table 8. Concentration of VOCs in Waste Boxes

Table 10. Data for the VOC's That Have Been Identified in High Concentrations in Drums

\section{LIST OF ACRONYMS}

\begin{tabular}{|c|c|}
\hline $\mathrm{ACM}$ & acrylic rubber \\
\hline DOT & Department of Transportation \\
\hline EPDM & ethylene propylene \\
\hline FRP & fiberglass-reinforced plywood \\
\hline LFL & lower flammability limit \\
\hline MDP & Matrix Depletion Program \\
\hline MDSA & Master Documented Safety Analysis \\
\hline NBR & Nitrile-butadiene rubber \\
\hline PR & product receiving \\
\hline PVC & polyvinyl chloride \\
\hline SWB & solid waste box \\
\hline SWOC & Solid Waste Operations Complex \\
\hline TRU & transuranic \\
\hline VOC & Volatile Organic Compound \\
\hline WIPP & Waste Isolation Pilot Plant \\
\hline
\end{tabular}




\subsection{ISSUE}

The Hanford Waste Management Project Master Documented Safety Analysis (MDSA) (HNF-14741, 2003) identifies derived safety controls to prevent or mitigate the risks of a singlecontainer deflagration during operations requiring moving, venting or opening transuranic (TRU)-waste containers. The issue is whether these safety controls are necessary for operations involving TRU-waste boxes that are being retrieved from burial at the Hanford Site. This paper investigates the potential for a deflagration hazard within these boxes and whether safety controls identified for drum deflagration hazards should be applied to operations involving these boxes.

\subsection{CONCLUSIONS}

The study evaluates the accumulation of hydrogen and VOCs within the waste box and the transport of these gases and vapors out of the waste box. To perform the analysis, there were numerous and major assumptions made regarding the generation rate and the transport pathway dimensions and their number. Since there is little actual data with regards to these assumptions, analyses of three potential configurations were performed to obtain some indication of the bounds of the issue (the concentration of hydrogen or flammable VOCs within a waste box). A brief description of each of the three cases along with the results of the analysis is summarized in the five points below. A tabular summary is shown next.

\begin{tabular}{|c|c|c|c|c|}
\hline \multirow[t]{2}{*}{ Case } & \multicolumn{2}{|c|}{$\begin{array}{c}\text { Base Case } \\
\text { Peak Concentration, } \\
\text { Vol\% after } 40 \text { years of burial } \\
\text { (See Note } 1)\end{array}$} & \multicolumn{2}{|c|}{$\begin{array}{c}\text { Base Case } \\
\text { Peak Pressure after } 40 \text { years of } \\
\text { burial, psig }\end{array}$} \\
\hline & Hydrogen & VOCs & Hydrogen & VOCs \\
\hline $\begin{array}{c}\text { Sealed Waste Box } \\
\text { (No gaps) }\end{array}$ & 32 & 9 & 7 & 1.5 \\
\hline $\begin{array}{l}\text { Waste box with } \\
\text { very small gaps in } \\
\text { the corners (gap is } \\
0.002 \text { inches wide) }\end{array}$ & 7.2 & 2.9 & 1.1 & 0.44 \\
\hline $\begin{array}{l}\text { Waste box with } \\
1 / 16 \text {-inch square } \\
\text { gaps in the corner }\end{array}$ & 1.5 & 4.2 & 0 & 0 \\
\hline $\begin{array}{l}\text { Waste box with } \\
\text { 1/8-inch square } \\
\text { gaps in the corner }\end{array}$ & 0.4 & 1.1 & 0 & 0 \\
\hline $\begin{array}{l}\text { Waste box with } \\
\text { 1/4-inch square } \\
\text { gaps in the corner }\end{array}$ & 0.1 & 0.3 & 0 & 0 \\
\hline
\end{tabular}


A waste box having at least 4 gaps, each of which being 1/32 inch wide and 0.75 inches long and having a VOC generation rate of $10^{-8} \mathrm{moles} / \mathrm{s}$ would have a VOC concentration of $12.8 \%$ upon retrieval. The concentration falls to the LFL for VOCs of $1 \%$ after 630 days outside, above ground. Waste boxes having fewer and/or smaller gaps require longer diffusion times. These times have not yet been determined. Waste boxes with larger gaps require shorter diffusion times.

A more detailed summary of the three cases is provided next.

1. ("Box with gaps" case) It is assumed that the gasket is segmented with gap of $1 / 16$ inch at each corner (the gap has a square cross-section with each side being $1 / 16$ inch), the gasket is 0.5 inches long (i.e., front to back) and the hydrogen generation rate is $4 \times 10^{-8}$ moles $/ \mathrm{s}$ (corresponding to $50 \mathrm{DE}-\mathrm{Ci}$ ). After 40 years of being retrievably stored (buried), the hydrogen concentration would be $1.5 \%$. This result is obtained for the base case waste box (about $7 \mathrm{ft}$. by $4 \mathrm{ft}$. by $4 \mathrm{ft}$.) as well as for the waste box that is 10 times larger. This hydrogen concentration is the concentration right at the time of retrieval. From the time of retrieval on, the hydrogen concentration would decrease due to the added transport of hydrogen out of the waste box due to atmospheric breathing.

It is assumed that VOCs were being generated (without hydrogen) in a waste box having 4 gaps between the lid and the body of the box, the gap width is $1 / 16$ inch, the gap length is $0.5 \mathrm{inch}$, and a generation rate of $10^{-8} \mathrm{moles} / \mathrm{s}$ (based on actual waste drum conditions, that is, the generation of VOCs in the waste box is the same as in drums having high VOC concentrations - See Section 4.8.2). Given these conditions, the VOC concentration after 40 years is $4.2 \%$. The concentration of $4.2 \%$ is greater than the lower flammability limit (LFL) for some VOCs. If the VOC generation rate were a more reasonable rate of $10^{-9} \mathrm{moles} / \mathrm{s}$, the VOC concentration would be $0.4 \%$.

The results of other cases run for VOCs are shown in Table 8, Concentration of VOCs in Waste Boxes in Section 4.8.2. The other cases include a gap of $1 / 32$ of an inch and gap length of $0.75 \mathrm{in.}$

Table 9, Concentration of VOCs in Waste Box after Retrieval shows that once the waste boxes are retrieved and atmospheric breathing can take place, the VOC concentration for the base case drops from $4.2 \%$ to $1 \%$ in 1 year. The concentration of $1 \%$ is essentially at or below the LFL for all of the VOCs identified in HNF-25634, Potential for a Volatile Organic Compound (VOC) Deflagration in a TRU Drum. Only trimethylbenzene has a lower LFL and it is $0.9 \%$. The concentration of the worst case presented in this analysis $\left(10^{-8} \mathrm{moles} / \mathrm{s}\right.$ generation rate, 4 gaps, each, $1 / 32$ inch wide and 0.75 inches long) drops from $12.8 \%$ to $1 \%$ in 630 days.

If the waste box were never buried the VOC concentration of the worst case conditions could be $0.3 \%$.

Therefore, a retrieved waste box must be allowed to breathe for 1.7 years to bring the concentration to below the LFL assuming: 
- 40 year burial

- $10^{-8} \mathrm{moles} / \mathrm{s}$ VOC generation rate

- Either $1 / 16$ or $1 / 32$ gap in the gasket

- Either 0.5 or 0.75 in. long gaskets.

2. "'Sealed box" case) It is assumed that the waste box contained no gaps in the gasket for leakage to occur. Table 5, Hydrogen Concentration from $50 \mathrm{DE}$-Ci from Alpha Emitters shows that the pressure in the waste box after 20 years and after 40 years is 7 psig and the hydrogen concentration is $32 \%$, if the waste box contains $50 \mathrm{DE}-\mathrm{Ci}$. A waste box that is 10 times larger than the base case box (which is assumed to be $7 \mathrm{ft}$ by $4 \mathrm{ft}$ by $4 \mathrm{ft}$ ) reaches the same steady state concentration and pressure at 120 years.

The results of other cases run for hydrogen are shown in Section 4.7.1.

If Volatile Organic Compounds (VOCs) were being generated at $10^{-8} \mathrm{moles} / \mathrm{s}$ and, there was no hydrogen generation and no leakage, the pressure would be $1.5 \mathrm{psig}$. The VOC concentration would be $9 \%$.

3. "Box with very small gaps" case) If very small gaps were present in the gasket (e.g., 0.002 inches) such that there was leakage due to forced flow (pressure differential) but diffusion through the gaps was small (as compared to leakage), the base case for hydrogen (50 DE-Ci in the waste box, $1.7 \mathrm{~cm}^{3} / \mathrm{min}$ leakage at $5 \mathrm{psig}$ ) shows a hydrogen concentration of $7.2 \%$ and waste box pressure of 1.1 psig.

The results of other cases run for hydrogen are shown in Section 4.7.1. The other cases include analysis of differing $\mathrm{DE}-\mathrm{Ci}, \mathrm{G}\left(\mathrm{H}_{2}\right)$ and leak rate values.

If the VOC generation rate was $10^{-8} \mathrm{moles} / \mathrm{s}$ (with no hydrogen generation) and there was the equivalent of $1.7 \mathrm{~cm}^{3} / \mathrm{min}$ leakage at $5 \mathrm{psig}$, the pressure would be $0.44 \mathrm{psig}$ and the VOC concentration would be $2.9 \%$.

4. Section 4.7.2 shows that the deflection of the lid or sides, of a waste box made of steel plates 0.375 inches thick with no bracing or stiffeners for the sealed box case is 0.65 inches for hydrogen, based on a pressure differential of 7 psig for the base case waste box (about $7 \mathrm{ft}$. by $4 \mathrm{ft}$. by $4 \mathrm{ft}$.). For the waste box that is 10 times larger, the deflection is about 30 times greater. For VOCs, the deflection for the base case waste box would be about 0.15 inches based on a pressure of $1.5 \mathrm{psig}$. The reason for the small deflection in the base case waste box is the stiffness of the 0.375 inch steel plate used in construction (per drawing H-2-74608).

For the "Box with very small gaps" case (item 3 above) the deflection is 2 inches for hydrogen based on a pressure of 1 psig for the base case waste box. For VOCs the deflection would be 0.8 inches based on a pressure of 0.44 psig.

However, the waste boxes do have stiffeners in the form of 3-inch angle iron every 16 inches all around. Therefore the deflection will likely be much less. 
5. The results of an investigation into environmental degradation shows that over a period of 40 years of burial, there will be no change that would suggest the potential for leakage over that already occurring through the gaps in the gaskets, with the possible exception of microbial attack.

Two references showed degradation due to microbial attack on neoprene. This suggests that it is a potential means for additional leakage paths to be generated. However, the extent and type of degradation was not quantified. Neither is there a readily identifiable way to assess the potential for degradation of gaskets of waste boxes buried at Hanford as compared to the conditions shown in the references.

\subsection{BACKGROUND}

Waste buried at several locations at the Hanford Site is being retrieved to be characterized and repackaged for disposal. The Solid Waste Operations Complex (SWOC) MDSA has analyzed the deflagration of accumulated flammable gas within a single container resulting in the ejection of a portion of the waste and some burning of both the ejected and remaining contents (see FIR-1 in the MDSA). Unique safety controls derived from the safety analysis are summarized in the following Table 1, Unique Safety Controls for Single Container Deflagration:

Table 1. Unique Safety Controls for Single Container Deflagration

\begin{tabular}{|l|l|}
\hline \multicolumn{1}{|c|}{ Safety Control } & \multicolumn{1}{c|}{ Safety Function } \\
\hline $\begin{array}{l}\text { Drum Venting System (safety- } \\
\text { significant structure, system or } \\
\text { component) }\end{array}$ & $-\begin{array}{l}\text { Reduces the likelihood of ignition by using } \\
\text { non-sparking and other methods. } \\
\text { Prevents ejection of bulk waste from the drum } \\
\text { during drum venting and protects workers from } \\
\text { hazards associated with the potential ejection of } \\
\text { the lid during drum venting. }\end{array}$ \\
\hline $\begin{array}{l}\text { Reduces the likelihood of a container lid } \\
\text { striking a worker }\end{array}$ \\
structure, system or component) & $-\begin{array}{l}\text { Provides a filtered pathway for venting } \\
\text { flammable gases, thus maintaining headspace } \\
\text { gases below hazardous levels. }\end{array}$ \\
\hline $\begin{array}{l}\text { Venting Waste Containers (technical } \\
\text { safety requirement - administrative } \\
\text { control) }\end{array}$ & $\begin{array}{l}\text { Requires use of container vent as discussed } \\
\text { above. } \\
\text { Requires lid restraint when venting drums } \\
\text { greater than or equal to 33 DE-Ci (including } \\
\text { package factor) to prevent ejection of bulk } \\
\text { waste materials. }\end{array}$ \\
\hline
\end{tabular}


Some TRU waste is buried in containers other than drums, such as boxes made of plywood, concrete or metal. Currently, no safety controls have been identified for the handling of these containers to address potential hazards associated with the accumulation of hydrogen. Two of these boxes are overpacks for other high Pu-mass TRU storage containers (i.e., L-10s with TRU-contaminated vermiculite and vented PR cans with solidified TRU-organic matrix. This report seeks to provide information regarding the potential for hydrogen accumulation in some of these containers and, if so, what are the appropriate controls.

To determine whether the accumulation of hydrogen in TRU-waste boxes is a potential hazard, it is first necessary to consider the types of waste boxes used at the Hanford Site. Boxes are used for storage of large, contaminated objects that cannot be accommodated by drums without requiring costly size reduction. These boxes have been purposely buried as unvented containers (e.g., no design element was included to ensure venting); however, it is possible that most boxes are capable of venting any gases generated because they are not tightly sealed. Descriptions of the boxes are provided in the following paragraphs.

\subsection{PLYWOOD BOXES}

Plywood boxes typically measure 84 inches long by 48 inches wide by 52 inches high and have a nominal capacity of $121 \mathrm{cu} \mathrm{ft}$. These boxes are nailed or screwed together and their joints and tops may be glued. Because of the porosity of the box material (wood and glue) and the likelihood the joints would not form a tight seal, plywood boxes are considered to be incapable of retaining hydrogen generated by the waste.

\subsection{FIBERGLASS-REINFORCED PLYWOOD BOXES}

Fiberglass-reinforced plywood boxes (FRPs) typically measure 84 inches long by 48 inches wide by 48 inches high and have a nominal capacity of $112 \mathrm{cu} \mathrm{ft}$. These boxes are nailed or screwed together and the joints are glued and taped with fiberglass tape. For the same reasons as for plywood boxes without the fiberglass reinforcement, FRPs are considered incapable of retaining hydrogen that is generated within the box. 
HNF-22524, Rev. 1

\subsection{CONCRETE BOXES}

Concrete boxes vary in size and have a nominal capacity of 125 to $190 \mathrm{cu} \mathrm{ft}$. These boxes are made of poured reinforced concrete and the top-to-body joints are caulked. The rate of transport of gases in concrete depends on such factors as material content of the cement, waterto-cement ratio, and porosity. The diffusivity of hydrogen through dry concrete is $3.9 \times 10^{-3} \mathrm{~cm}^{2} / \mathrm{s}$ per Table 4-1 of RPP-12710, Flammable Gas Diffusion from Waste Transfer Associated Structures. By comparison, the diffusion coefficient of hydrogen through rubber is $10^{-6}$ to $10^{-5} \mathrm{~cm}^{2} / \mathrm{s}$ per Table 2 of the reference. The difference is that concrete is porous (with a tortuous path). Given the large diffusion coefficient and the large area for mass transfer, it is not expected that hydrogen would accumulate within these boxes.

\subsection{METAL BOXES}

Metal boxes typically measure ( $\mathrm{L} \times \mathrm{W} \times \mathrm{H}) 7 \mathrm{ft} \times 4 \mathrm{ft} \times 4 \mathrm{ft}, 6 \mathrm{ft} \times 5 \mathrm{ft} \times 4 \mathrm{ft}, 7 \mathrm{ft} \times 5 \mathrm{ft} \times$ $5 \mathrm{ft}$ and some larger than these. For purposes of the analysis, the waste box will be assumed to have dimensions of 53 inches $\times 50$ inches $x 72$ inches high and have a nominal capacity of $113 \mathrm{cu} \mathrm{ft}$. This is approximately the volume of solid waste boxes (SWBs) used at the Waste Isolation Pilot Plant (WIPP). The WIPP SWB is 10 gauge (0.132 inches) and has rounded ends. The base and side joints are welded, and the lid is fastened with bolts. The lid-to-body interface is gasketed with an ethylene propylene rubber (EPDM) material. The gasket size is about 0.5 inch wide and 0.5 inch tall. It will be shown in Section 4.0 that the gasket size is not critical. The box material is considered to provide a barrier against diffusion of hydrogen. While the integrity of the welded joints would become suspect (because the boxes undergo torsion and compression as they are stacked and covered with overburden), it is reasonable to assume the properties of the welds are the same as that of the metal with respect to providing a barrier to gas release. Historically, gasket use was intended to prevent water or other liquids from intruding upon the waste within the box, and no specifications were established to maintain gases within the box. The gaskets were placed on the edges of the box body. The gaskets were butted at the corner but there was no requirement to have the corner sealed. The lid was then butted to the body. This likely compressed the gaskets. Experience at T Plant is that essentially all of the rectangular shape waste boxes have 4-piece gaskets that are glued onto the metal surfaces. This is also shown in the drawing of the metal waste box (Drawing H-2-74608, sheet 1, Section D5). The drawing also shows that the comers are not glued as no glue is shown as it is in the gasket splice shown in sheet 1, Section C5. Experience also is that the gaskets have to be reglued on occasion when reclosing the boxes. Therefore, the gasketed lid-to-body interface and the corners where the gaskets meet are possible leakpaths for hydrogen.

At a meeting held on August 14 between long-time members of Solid Waste Engineering, Operations Support and Projects, JD Anderson said that the waste boxes were drop tested and only those that passed were used. The drop test consisted of adding a detectable powder to the interior of the waste box, sealing the powder insertion opening and dropping the waste box from $4 \mathrm{ft}$. A detector was used to determine if the waste box leaked by looking for powder on the outside of the box. However, the box is very strong. It is made of 3/8 inch ASTM A36 steel plate. There are $\mathrm{C} 8 \times 13.75$ channels ( 8 inches tall, 2.34 inches across at top and base with a 0.3 inch thick wall) an 18 to 20 inch centers all around the waste box (on all sides, top and 
bottom). As a result, the box will not flex much. Since the box will not flex much, there is little pressure to push the powder out. As a result a waste box having a gasket with gaps in the corner could pass the drop test.

Another style of metal box is the B-25 box. This box is about 6 feet $x 4$ feet $x 4$ feet. The lid overlaps the sides and is held on by four spring clips. There is a gasket between the lid and the walls of the box. These boxes are Department of Transportation (DOT) qualified.

The analysis is performed assuming that the waste box is about $7 \mathrm{ft}$. by $4 \mathrm{ft}$. by $4 \mathrm{ft}$. A sensitivity analysis is performed with a volume that is ten times larger to determine the effects in much larger waste boxes.

\subsection{PATH FORWARD}

The remaining discussion will examine the generation and diffusion of hydrogen and volatile organic carbon vapors from a metal TRU-waste box.

\subsection{ANALYSIS OF HYDROGEN AND VOLATILE ORGANIC CARBON (VOC) VAPOR RETENTION IN TRU WASTE BOXES}

\subsection{METHODOLOGY}

The approach is to assess the potential for hydrogen accumulation in a metal TRU waste box. The chosen method is to use a conservative analytical approach to determine whether it is possible for the hydrogen concentration to reach the lower flammability limit (LFL) during the time period that the box is closed.

\subsection{THE POTENTIAL FOR HYDROGEN ACCUMULATION}

While there may be more than one mechanism for hydrogen to be transported out of the waste box, it is conservative to start with the assumption that hydrogen is lost only by diffusion through the gasket material and through the gaps in the gasket or by pressure-driven leakage out through any openings.

In the calculations to follow, it is assumed that hydrogen is uniformly distributed throughout the void volume. This assumption is consistent with testing results from the Savannah River Site (Transuranic Drum Hydrogen Explosion Tests, WSRC-TR-90-165, 1990) that indicated hydrogen injected into a closed drum became uniformly distributed throughout the drum within an hour. 


\subsection{DIFFUSION AND LEAKAGE THROUGH THE GASKET}

Modeling diffusion of gas through a gasket requires a membrane equation. The diffusion of a gas through a membrane is given below. The equations are taken from Chapter 17 of the textbook Diffusion: Mass Transfer in Fluid Systems (Cussler 1997). The flux of hydrogen across a membrane is given by:

where $\mathrm{j}=$ mass flux, moles $/ \mathrm{cm}^{2}$-s

$$
j=\frac{D}{l}\left(c_{0}-c_{1}\right)
$$

$\mathrm{D}=$ Diffusion coefficient, $\mathrm{cm}^{2} / \mathrm{s}$

$\mathrm{c}_{0}=$ hydrogen concentration within the membrane at one edge, moles $/ \mathrm{cm}^{3}$

$c_{1}=$ hydrogen concentration within the membrane at the opposite edge, moles $/ \mathrm{cm}^{3}$

$\mathrm{I}=$ the thickness of the membrane, $\mathrm{cm}$

An important aspect of diffusion across a membrane is that the flux is also a function of the partition between the gas in the membrane and that in the surrounding fluid. This results in an equation for flux of:

$$
j=\frac{H D}{l}\left(C_{0}-C_{1}\right)
$$

where $\mathrm{H}=$ partition coefficient or the solubility between the membrane and the surrounding fluid

$\mathrm{C}_{0}=$ Concentration of hydrogen in the fluid on one side of membrane, moles $/ \mathrm{cm}^{3}$

$\mathrm{C}_{1}=$ Concentration of hydrogen in the fluid on the opposite side of the membrane, moles $/ \mathrm{cm}^{3}$

$D, j$, and $\mathrm{l}=$ are defined as above.

The term "HD" is the permeability of the membrane.

The gaskets are made from EPDM rubber. The handbook entitled Permeability and other Film Properties of Plastics and Elastomers (1995) provides the permeability of hydrogen and air in various rubbers. The data is provided in Table 2a, Permeability of Various Gases in Various Rubbers at 23C-25C (Notes 1,2) below. 
HNF-22524, Rev. 1

Table 2a. Permeability of Various Gases in Various Rubbers at 23C-25C (Notes 1, 2)

\begin{tabular}{|c|c|c|c|c|c|c|}
\hline $\begin{array}{l}\text { Rubber } \\
\text { type }\end{array}$ & $\mathrm{CO}_{2}$ & Air & $\mathbf{O}_{2}$ & $\mathbf{N}_{2}$ & $\mathrm{He}_{2}$ & $\mathbf{H}_{2}$ \\
\hline EPDM & 90 & 9.5 & 20 & 7 & ---.- & ------ \\
\hline $\begin{array}{l}\text { Fluro, } \\
\text { FKM } \\
\text { (Viton) }\end{array}$ & $5.9(30 \mathrm{C})$ & 0.1 & $1.1(30 \mathrm{C})$ & 0.054 & 8.9 & $-\ldots$ \\
\hline Butadiene & 90 & ----- & ----- & 9 & ----- & ----- \\
\hline Silicone & 1400 & ----- & 227 & $200(21 C)$ & ---- & 205 \\
\hline $\begin{array}{l}\text { Styrene } \\
\text { Butadiene }\end{array}$ & 4.5 & 4 & 14 & $4.8(21 C)$ & ---- & ---- \\
\hline
\end{tabular}

Chapter 86 of the reference book Permeability Properties of Plastics and Elastomers $-A$ Guide to Packaging and Barrier Materials (2003) provides the permeability of air and hydrogen through natural rubber. Table $86-02$ provides the permeability coefficient for air at $23.9{ }^{\circ} \mathrm{C}$. The value is

$$
\frac{496 \mathrm{~cm}^{3}-m m}{m^{2}-d a y-a t m} \text { or } \frac{5.7 \times 10^{-8} \mathrm{~cm}^{3}-\mathrm{cm}}{\mathrm{cm}^{2}-s-a t m}
$$

Table 86-01 shows that in natural rubber the permeability of air is $46 \%$ that of hydrogen.

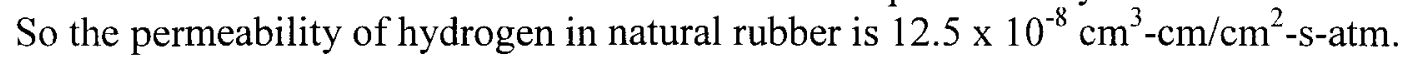

Table 86-04 shows that the permeability of hydrogen through natural rubber is $667 \%$ that through butyl rubber. Therefore, the permeability of hydrogen through butyl rubber is $1.87 \mathrm{x}$ $10^{-8} \mathrm{~cm}^{3}-\mathrm{cm} / \mathrm{cm}^{2}-\mathrm{s}-\mathrm{atm}$. Other tables within the reference provide the permeability of hydrogen as a percentage of that through natural rubber. Using this method and other tables within the reference, permeabilities through other kinds of rubber are determined. Table 2b, Permeability of Hydrogen through Various Kinds of Rubber - Data from Permeability Properties provides the data. 
HNF-22524, Rev. 1

Table 2b. Permeability of Hydrogen Through Various Kinds of Rubber Data from Permeability Properties

\begin{tabular}{|l|c|c|}
\hline \multicolumn{1}{|c|}{ Rubber } & Permeability & Table of Reference \\
\hline Natural & 12.5 & $86-01$ \\
\hline Butyl & 1.87 & $86-04$ \\
\hline Polybutadiene & 10.8 & $76-03$ \\
\hline Isobutylene & 1.63 & $80-01$ \\
\hline Polychloroprene (neoprene) & 3.37 & $87-01$ \\
\hline \multirow{2}{*}{ Silicone } & 134 & $91-01$ \\
\cline { 2 - 3 } & 205 & $91-03$ \\
\hline Styrene-butadiene & 12 & $92-02$ \\
\hline Note 1 - Units are $\mathrm{cm}^{3}-\mathrm{cm}^{\prime} \mathrm{cm}^{2}$-s-atm \\
\hline
\end{tabular}

The Polymer Handbook (1999) provides the following permeability data for hydrogen through various elastomers.

Table 2c. Permeability of Hydrogen Through Various Kinds of Rubber Data From Polymer Handbook

\begin{tabular}{|l|c|}
\hline \multicolumn{1}{|c|}{ Rubber } & Permeability $^{(\text {(I) }}$ \\
\hline Neoprene G & 10.2 \\
\hline Neoprene & 20.7 \\
\hline $\begin{array}{l}\text { Dimethyl butadiene } \\
\text { (Methyl Rubber) }\end{array}$ & 12.8 \\
\hline Butyl Rubber & 5.43 \\
\hline Isoprene & 10.9 \\
\hline Silicon Rubber & 348 \\
\hline Note 1-Units are $\mathrm{cm}^{3}$-cm/ $/ \mathrm{cm}^{2}$-s-atm \\
\hline
\end{tabular}

In the analysis to follow the permeability is chosen to be $12 \mathrm{~cm}^{3}-\mathrm{cm} / \mathrm{cm}^{2}-\mathrm{s}-\mathrm{atm}$.

It will be shown below that the peak hydrogen concentration is not sensitive to the numerical value chosen for permeability.

The diffusion of hydrogen out of the waste box gasket is found from the equation below. The pressure gradient is used in the equation below because it is related to the concentration gradient and is the equation used when the units on "HD" are as shown.

$$
q_{l}=\frac{(H D)(\text { area })(\Delta P)}{l} \mathrm{~cm}^{3} / \mathrm{s}
$$

where $\mathrm{HD}=$ permeability, $12 \times 10^{-8} \mathrm{~cm}^{3}-\mathrm{cm} / \mathrm{cm}^{2} \mathrm{~s}-$ atm

area $=$ length times height of the gasket, $\mathrm{cm}^{2}$. The length is $(2 * 53$ inches long $+2 * 50$ inches wide) or $206 \mathrm{in}$. long or $523 \mathrm{~cm}$. The height is $0.5 \mathrm{~cm}$.

The area is then $262 \mathrm{~cm}^{2}$.

$1=$ length of the transfer path in the gasket or $1.27 \mathrm{~cm}$ (from 0.5 inch wide). 


$$
\mathrm{q}_{\mathrm{D}}=\text { rate of hydrogen transport out by diffusion, } \mathrm{cm}^{3} / \mathrm{s}
$$

Substituting yields:

$$
\mathrm{q}_{\mathrm{D}}=2.5 \times 10^{-5}(\Delta \mathrm{P}) \mathrm{cm}^{3} / \mathrm{s} \text { or } 0.09(\Delta \mathrm{P}) \mathrm{cm}^{3} / \mathrm{hr} \text {, }
$$

where $\Delta \mathrm{P}$ is the pressure differential across the gasket in atm. It will be shown later that the peak hydrogen concentration is not sensitive to the gasket size.

Another means of hydrogen transport out of the box is leakage. Report DP-1604, Radiogenic Gas Accumulation in TRU Waste Storage Drums, discusses leakage from drums. The four drums that they tested leaked. The leak rate vs. pressure was found to be proportional to the square root of the pressure differential, or

$$
\text { Leakage, } \mathrm{cm}^{3} / \min =\operatorname{constant}^{*}(\Delta \mathrm{P})^{0.5}
$$

They measured leakages of $1.7 \mathrm{~cm}^{3} / \mathrm{min}$ with a $\Delta \mathrm{P}$ of $5.4 \mathrm{psig}$ and leakage of $0.4 \mathrm{~cm}^{3} / \mathrm{min}$ from a $\Delta \mathrm{P}$ of $0.25 \mathrm{psig}$. They also stated that in other experiments, leakage was at least

$1 \mathrm{~cm}^{3} / \mathrm{min}$-psig no matter how tightly the lid was fastened. One might expect the leakage from a waste box to be greater than that from a drum as the perimeter of the gasket is much greater. In addition, the gasket can be comprised of more than one piece resulting in potential leak paths where the pieces meet. Lastly, the waste box lid is bolted on. The potential exists for gaps due to uneven pressures on the waste box lid during lid closure.

For purposes of this analysis, the leakage equation for the waste box is assumed to follow the relationship for the drum. The leakage value used in the spreadsheet is $1.7 \mathrm{~cm}^{3} / \mathrm{min}$ at $5 \mathrm{psig}$. A sensitivity calculation is performed to determine the effect of leakage rate.

The last means by which hydrogen can be transported out of the waste box is via diffusion through the leakage paths shown in Section 4.8.1.

A spreadsheet was devised to determine the hydrogen concentration in the waste box. However, the spreadsheet requires information concerning hydrogen generation, waste box radionuclide inventory and the fraction of the inventory that is in close proximity to the materials that can be degraded by radiolysis

\subsection{HYDROGEN GENERATION RATE}

Studies of hydrogen generation in waste drums have been performed to predict the amount of hydrogen that can be generated given the characteristics of the waste and waste storage conditions. The possible mechanisms for hydrogen generation are understood to be the oxidation of metal from reaction with water and the radiolysis of hydrogenous material in a radioactive environment. Under typical waste storage conditions, hydrogen generation from metal-water reaction is not expected to be a concern because of deliberate efforts to prevent water in-leakage (use of gaskets for seals, for example), limited amount of reactive metallic forms, and the lack of high temperatures favorable to the reaction. Therefore, hydrogen 
generation caused by metal-water reaction is not considered, and the remainder of this discussion will focus on hydrogen generation from the radiolysis of hydrogenous material.

The amount of hydrogen generated from radiolysis will depend on many factorsspecifically, the type, form and activity of the radioactive material; the composition and amount of the target material; and the distribution of the radioactive material within the target material. Because these factors might be unknown and differ with every waste container, gas generation rates cannot be accurately predicted for any particular container.

The hydrogen generation rate is found by determining the value for $\mathrm{G}\left(\mathrm{H}_{2}\right)$ for the waste. Savannah River Report DP-1604 (1982) provides an estimate of $\mathrm{G}\left(\mathrm{H}_{2}\right)$ for waste based on that for typical waste materials (cellulosics, polyethylene, oil, polyvinyl chloride [PVC]) and on that calculated from the gas generation from 4 drums that were filled with various combinations of contaminated wastes, including gloves, metal and plastic containers, small equipment like balances, plastic sheeting, tools and pipe and sampled periodically over a 4 year period of time. In both cases, the report shows a value for G(Total gas) of 2.0 molecules per $100 \mathrm{eV}$ for contaminated waste within a drum, contaminated cellulose, polyethylene and pump oil, and a value of approximately 9 for contaminated PVC. They also found that the pressure was rising at about the same rate after 4 years. A value of 2 molecules per $100 \mathrm{eV}$ results in a gas generation rate of $14 \mathrm{~cm}^{3} /$ day-Ci assuming radiation energy of $5.2 \times 10^{6}$ ev/disintegration (from ${ }^{239} \mathrm{Pu}$ ).

In contrast, Los Alamos report LA-7674-MS, Gas Generation from Radiolytic Attack of TRU-Contaminated Hydrogenous Waste (1979), showed initial gas generation rates about half to $3 / 4$ of those found in DP-1604 for similarly contaminated drums. This report showed that the generation rate decreased to about $1 / 3$ of the initial value after 4.5 years of the experiment. This phenomena of degradation (or reduction) of the generation rate is called "matrix depletion". HNF-9411, Analysis of Available Hydrogen Data and Accumulation of Hydrogen in Unvented TRU Drums discussed the "Matrix Depletion" program in which tests were performed to determine if the hydrogen generation rate did, indeed, decrease with time. The three-year program concluded that the hydrogen generation rate did decrease with time. Results from the Matrix Depletion Program (MDP) are described in detail in the MDP final report (INEL/EXT98-00987, 1999), TRUPACT-II Matrix Depletion Program Final Report and are summarized in Table 3, Experimental Dose-Dependent $G$ Values in terms of the dose-dependent G values for each waste matrix tested.

For all waste matrices, these dose-dependent $\mathrm{G}$ values were achieved within a maximum dose of 0.006 watt*year (product of watts times years). For example, for a waste container with a watt loading of 0.1 watt, the dose-dependent $G$ value shown in Table 3 would be reached after 0.06 years or 22 days. The lower the watt loading, the longer it would take for the watt*year criteria to be satisfied and the dose-dependent $G$ value to be applicable. Figure 4-8 of the reference suggests that these values do not decrease further over time. 
HNF-22524, Rev. 1

Table 3. Experimental Dose-Dependent G Values

\begin{tabular}{|c|c|c|c|}
\hline \multirow{2}{*}{ Matrix } & \multirow{2}{*}{$\begin{array}{l}\text { Value of } \mathbf{G}\left(\mathrm{H}_{2}\right) \\
\text { used prior to the } \\
\text { Matrix Depletion } \\
\text { Program tests }\end{array}$} & \multicolumn{2}{|c|}{$\begin{array}{l}\text { Experimental Dose-Dependent G Values } \\
\text { (From the Matrix Depletion Program) }\end{array}$} \\
\hline & & Mean & 95\% Percentile \\
\hline Cement & 1.3 & 0.25 & 0.49 \\
\hline Dry Cellulose & 3.4 & 0.27 & 0.49 \\
\hline Polyethylene & 3.4 & 0.23 & 0.56 \\
\hline Polyvinyl Chloride & 3.4 & 0.14 & 0.44 \\
\hline Wet Cellulose & 3.4 & 0.44 & 0.99 \\
\hline
\end{tabular}

The following conclusions can be drawn from the results of the Matrix Depletion Program.

- Increasing dose (product of the decay heat loading and elapsed time) decreases the effective $G$ value for hydrogen due to depletion of the matrix in the vicinity of the alphaemitting radioactive source particle. The lower $\mathrm{G}$ value, called the "dose-dependent $\mathrm{G}$ value" is applicable after a dose of 0.006 watt*years.

- As with initial $\mathrm{G}$ values, the dose-dependent $\mathrm{G}$ values are a function of the waste matrix.

- Dose-dependent $\mathrm{G}$ values for wet cellulosics were higher than those for dry cellulosics because of the presence of water.

- The dose-dependent $G$ values were independent of temperature based on testing performed at room temperature and at $140^{\circ} \mathrm{F}$.

- Experiments performed with different particle sizes show that while initial G values could be higher for smaller particle sizes, the dose-dependent $\mathrm{G}$ values for all particle sizes tested are bounded by the values shown in Table 1 .

- Previous experiments that included agitation of cylinders similar to those used in the MDP indicated that agitation did not affect dose-dependent $\mathrm{G}$ values.

- Isotopic composition did not have a significant impact on the dose-dependent G values based on experiments performed with two different isotopes of $\mathrm{Pu}\left({ }^{238} \mathrm{Pu}\right.$ and $\left.{ }^{239} \mathrm{Pu}\right)$.

Data from actual CH-TRU waste containers at the Rocky Flats Environmental Technology Site and the Idaho National Engineering and Environmental Laboratory show that even when compared to the mean dose-dependent $G$ values from the matrix depletion experiments, apparent $G$ values from real waste containers are lower. Theoretical analysis, using nuclear and molecular level mechanisms, also shows that hydrogen generation from radiolysis and matrix depletion is consistent with the experimental results from the MDP. 
Studies performed at Rocky Flats in the 1980's [Probabilistic Risk Assessment of Hydrogen Generation in Drums Containing Plutonium-Contaminated Materials (Restrepo 1989)] also provide rates for gas yields of certain materials contaminated with plutonium (primarily ${ }^{239} \mathrm{Pu}$ ). These values are expressed in $\mathrm{cm}^{3}$ per day per Curie of plutonium for several components of waste material capable of generating hydrogen. Table 4, Gas Yields $\left(\mathrm{cm}^{3} /\right.$ day-Ci) for use in Risk Assessments for Plutonium-Contaminated Material provides the reported values: The third column values are found by assuming that the radiation energy is $5.2 \mathrm{Mev} /$ disintegration.

Table 4. Gas Yields ( $\left.\mathrm{cm}^{3} / \mathrm{day}-\mathrm{Ci}\right)$ for use in Risk Assessments for Plutonium-Contaminated Material (Source: Restrepo 1989, Table 7)

\begin{tabular}{|l|c|c|}
\hline \multicolumn{1}{|c|}{ Contaminated Material } & Gas Yield & $\begin{array}{c}\text { G(gas) assuming } \\
\text { 5.2 Mev/dis }\end{array}$ \\
\hline Plexiglas & 2.0 & 0.3 \\
\hline Polyvinyl chloride & 3.0 & 0.45 \\
\hline Leaded gloves & 2.0 & 0.3 \\
\hline Machining oil & 10.0 & 1.5 \\
\hline Chlorothen & 2.0 & 0.3 \\
\hline Carbon tetrachloride & 0.1 & 0.015 \\
\hline Kimwipes & 4.0 & 0.6 \\
\hline Polyethylene & 5.0 & 0.75 \\
\hline Ion exchange resin & 1.0 & 0.15 \\
\hline Surgeon's gloves & 3.0 & 0.45 \\
\hline Ash-heel & 0.1 & 0.015 \\
\hline Sludge & 2.0 & 0.3 \\
\hline Grease & 10.0 & 1.5 \\
\hline Combustibles & 2.0 & 0.3 \\
\hline Plastic and rubber & 2.0 & 0.3 \\
\hline
\end{tabular}

Table 3 of DP-1604 (1982) shows that of the gases that are generated, the fraction that is hydrogen ranges from about 0.95 for polyethylene to about 0.6 for cellulosics. The hydrogen fraction in the 4 test drums ranged from 0.45 to 0.05 . LA-7674-MS (1979) showed hydrogen fractions of 0.95 for a test chamber containing only polyethylene. A test cylinder containing cellulosics, plastic and rubber showed a hydrogen fraction of 0.7 at about 4 years with the trend starting to turn downward (to lower hydrogen fractions). A test cylinder containing dry cellulosics had a hydrogen fraction of 0.6 after about 4 years and is leveling off.

For this analysis, a value for $\mathrm{G}\left(\mathrm{H}_{2}\right)$ of 0.5 is used based on the Rocky Flats data and the values in INEL/EXT-98-00987 (1999). Included in the choice is the assumption that large quantities of wet cellulose are not present. This is a conservative value in that the mean values from Table 3 could be used to argue that a more realistic value for $\mathrm{G}\left(\mathrm{H}_{2}\right)$ is 0.3 . 


\subsection{WASTE BOX INVENTORY}

The curie loading in the waste box is chosen to be $50 \mathrm{DE}-\mathrm{Ci}$ from alpha emitters. The average curie content of the 56 waste boxes shown in Appendix A is 26.4 De-Ci from alpha emitters. The greatest curie content in a waste box is $79.4 \mathrm{DE}-\mathrm{Ci}$. The least is $6.9 \mathrm{DE}-\mathrm{Ci}$. The value of $50 \mathrm{DE}-\mathrm{Ci}$ is twice the average of all metal TRU-waste boxes shown in Appendix A and bounds all but 7 of those boxes. A sensitivity to this value is also performed.

\subsection{FRACTION OF THE INVENTORY THAT AFFECTS THE WASTE}

Appendix A shows the inventory and contents of 56 waste boxes. All of the waste boxes contain either metal or cement or both. Of the 56 waste boxes, 26 have no hydrogenous material in them and therefore are not of concern regarding radiolysis. Of the 56 boxes, 6 have only metal (and/or glass) and plastic, possibly indicating a wrapped piece of equipment. This leaves 24 waste boxes that have a variety of materials. The typical mix is paper, wood, plastic, metal, cloth and sometimes glass. The average inventory in these boxes is $35 \mathrm{DE}-\mathrm{Ci}$ from alpha emitters. Some of this waste is likely within equipment in which the radiation is either shielded from the organic or is separated from the hydrogen material. Some of the radioactive contamination is located on waste that contains no hydrogenous material or that has a low value of $\mathrm{G}\left(\mathrm{H}_{2}\right)$. Therefore, it is judged that a reasonable estimate of the fraction of the inventory that is involved in radiolytically degrading the waste is 0.5 . This value is also used in INEL/EXT-9800987 (1999), Section 4.4, paragraph 4.

\subsection{DIFFUSION AND LEAKAGE SPREADSHEET FOR A PRESSURIZED WASTE BOX}

In this case the gaps in the gasket are extremely small such that the waste box can pressurize. Section 4.8 covers the case where the gaps are large enough that the waste box does not pressurize.

\subsubsection{Diffusion and Leakage of Hydrogen in Pressurized Waste Boxes}

A spreadsheet was developed to determine the pressure and hydrogen concentration within a waste box after 20 years, given an input hydrogen rate and accounting for diffusion and leakage. A sensitivity analysis was performed for the base case (see Note 1 to Table 5) to consider 40 year burial and to consider larger waste boxes. The base case waste box is assumed to be $7 \mathrm{ft}$ by $4 \mathrm{ft}$ by $4 \mathrm{ft}$.

The flow of the spreadsheet is as follows:

1. The hydrogen generation rate is determined first. The alpha energy is chosen. A value of $5.2 \times 10^{6} \mathrm{ev}\left(\right.$ for ${ }^{239} \mathrm{Pu}$ ) is used in the calculation. From above, a value of 0.5 is used to approximate the fraction of the waste that can irradiate plastics, rubber and other organics. The value for $\mathrm{G}\left(\mathrm{H}_{2}\right)$ is chosen. In the example, the value of $\mathrm{G}\left(\mathrm{H}_{2}\right)$ is 0.5 . The value for "L/mole" is taken from the ideal gas law for a case where the pressure is $1 \mathrm{~atm}$ and the 
temperature is $298 \mathrm{~K}$. This data and that above is used to determine a hydrogen generation rate in units of $\mathrm{cm}^{3} / \mathrm{hr}$ in the following manner:

$\mathrm{H}_{2}$ rate $=$

$\left(\frac{0.5 \text { molec. }}{100 e v}\right)\left(\frac{5.2 \times 10^{6} \mathrm{ev}}{d i s}\right)\left(\frac{3.7 \times 10^{10} \mathrm{dis}}{s-C i}\right)\left(\frac{24.45 \mathrm{~L}}{\text { mole }}\right)\left(\frac{1000 \mathrm{~cm}^{3}}{L}\right)\left(\frac{3600 \mathrm{~s}}{\mathrm{hr}}\right)\left(\frac{\text { mole }}{6.02 \times 10^{2.3} \text { molec. }}\right)(50 C i)(0.5)$

$=3.5 \mathrm{~cm}^{3} / \mathrm{hr}\left(4 \times 10^{-8}\right.$ moles $\left./ \mathrm{s}\right)$

2. The hydrogen generation over a chosen period of time $(\Delta t)$ is determined. Units are $\mathrm{cm}^{3}$. These are then converted to moles.

3. Initially there is no hydrogen in the box.

4. At the end of the chosen period, the amount of hydrogen in the box comes from adding the generation (Step 2) to the hydrogen present at the end of the previous time step, minus the amount transported out due to diffusion and leakage, taken from Steps 7 and 8.

5. The hydrogen fraction and box pressure are determined. The box pressure comes from the ideal gas law assuming no oxygen depletion, the new hydrogen quantity in the waste box, and the existing air in the waste box.

6. The $\Delta \mathrm{p}$ (the pressure differential) between box and outside area is calculated. The outside area is assumed to have a volume 10 times that of an empty box. This is not a crucial assumption. The area outside the waste box is given a volume so that it is easier to determine the hydrogen concentration outside of the box (rather than assume it is always zero).

7. The permeability is determined from:

$$
q_{D}=\frac{(H D)(\operatorname{area})(\Delta P)}{l} \mathrm{~cm}^{3} / \mathrm{s}
$$

The value of the permeability "HD" is taken from above, as are the area and the length.

From this, the diffusion flow into the outside area is determined using the equation for "qD" above. The rate is then transformed into a value in "moles in the time period" by dividing by $1000 \mathrm{~cm}^{3} / \mathrm{L}$, dividing by $24.45 \mathrm{~L} /$ mole (at $298 \mathrm{~K}$ ) and by multiplying by the value of $\Delta \mathrm{P}$ and the seconds in a time step.

8. Leakage is also considered. Leakage is based on $1.7 \mathrm{~cm}^{3} / \mathrm{min}$ given a $\Delta \mathrm{P}$ of $5 \mathrm{psig}$ and a square root dependence on $\Delta \mathrm{P}$. The leakage rate of hydrogen out of the waste box is found from: 
Leakage, moles in the time period $=$

$$
\left(\frac{1.7 \mathrm{~cm}^{3}}{\min }\right)\left(\frac{60 \mathrm{~min}}{h r}\right)\left(\frac{\mathrm{hr}}{\text { timestep }}\right)\left(\frac{\Delta P}{5 \mathrm{psig}}\right)^{0.5}\left(\frac{\text { conc._of _ } H_{2} \text { in_t }_{-} \text {the_box, moles }}{L}\right)\left(\frac{L}{1000 \mathrm{~cm}}\right)
$$

The leakage of air is discussed in step 10 , below.

The opening size to which this leakage corresponds is found as follows. The leakage diameter is not used in the calculation. It is discussed here to give a sense of the opening size that corresponds to the leakage rate chosen.

The opening that will allow a flow rate of $1.7 \mathrm{~cm}^{3} / \mathrm{min}$ at $5 \mathrm{psig}$ will be determined. The opening is through a gasket. Frictional losses occur in the path. The flow through a "pipe" is given on page 3-4 of Flow of Fluids through Valves, Fittings and Pipe, Crane Technical Paper No. 410 (CTP 410, 1951) as:

$$
q_{m}=412 Y d^{2}\left(\frac{\Delta P \rho_{i}}{K}\right)^{0.5}\left(\frac{1}{S_{g}}\right)
$$

where $\mathrm{q}_{\mathrm{m}}=$ flow rate in $\mathrm{ft}^{3} / \mathrm{min}$

$$
\begin{aligned}
& =\left(1.7 \mathrm{~cm}^{3} / \mathrm{min}\right)(\mathrm{ft} / 30.5 \mathrm{~cm})^{3} \\
& =6 \times 10^{-5} \mathrm{ft}^{3} / \mathrm{min}
\end{aligned}
$$

$\mathrm{d}=$ diameter of the pipe, in.

$\Delta \mathrm{P}=$ pressure drop, $\mathrm{psig}$

$=5 \mathrm{psig}$

$\rho=$ upstream density, $\mathrm{lb} / \mathrm{ft}^{3}$

$=1.59 \mathrm{~g} / \mathrm{L}$ at $298 \mathrm{~K}$ and $5 \mathrm{psig}$

$=0.1 \mathrm{lb} / \mathrm{ft}^{3}$

$\mathrm{S}_{\mathrm{g}}=$ specific gravity of gas as compared to air $=1.0$ in this case

$\mathrm{K}=$ frictional loss coefficient

$=\mathrm{f}(\mathrm{L} / \mathrm{D})+$ Entrance + Exit

$\mathrm{L}=$ Length of flow path, in.

$=(1.27 \mathrm{~cm}) /(2.54 \mathrm{~cm} / \mathrm{in})$

$=0.5 \mathrm{in}$.

$\mathrm{D}=$ diameter of the pipe, in. (= "d" above)

$\mathrm{f}=$ friction factor, a function of Reynolds number (see below)

$\mathrm{Y}=$ Expansion factor (page A-22 of reference) for large values of $\mathrm{K}, \mathrm{Y}$ is about 0.90

Entrance $=0.5$ (page A-26 of reference based on a square edge entrance)

Exit $=1.0$ (page A-26 of reference based on a square edge exit)

The friction factor " $\mathrm{f}$ " is a function of the Reynolds number "Re" where

$$
\operatorname{Re}=123.9 \frac{d v \rho_{i}}{\mu} \quad \text { (page 3-2 of reference) }
$$

Where $\mathrm{d}=$ diameter, in 


$$
\begin{aligned}
\mathrm{v} & =\text { velocity out opening, } \mathrm{ft} / \mathrm{s} \\
\rho_{\mathrm{i}} & =\text { density, } \mathrm{lb} / \mathrm{ft}^{3} \\
& =0.1 \mathrm{lb} / \mathrm{ft}^{3} \\
\mu & =\text { viscosity of flowing fluid (air, in this case), centipoise } \\
& =0.018 \text { (page } \mathrm{A}-5 \text { of reference) }
\end{aligned}
$$

Assume laminar flow. Then $\mathrm{f}=64 / \mathrm{Re}$. Solving for "d" yields 0.0019 in (or $50 \mu \mathrm{m}$ ). The solution also confirms that the flow is laminar as "Re" is 66 . If the gasket length were 1 inch, not $0.5 \mathrm{in}$, then "d" would be $0.0023 \mathrm{in}$. If the flow were $8.5 \mathrm{~cm}^{3} / \mathrm{min}$, not $1.7 \mathrm{~cm}^{3} / \mathrm{min}$, "d" would be 0.0029 in.

9. The hydrogen loss from diffusion and leakage are added. This quantity flows into the outside volume. For these very small hole sizes the resistance to diffusion flow is very large. The flow of hydrogen due to diffusion out the gaps is negligible compared to forced flow.

10. The new hydrogen concentration and pressure in the outside volume are calculated.

The leakage of air out of the opening and the generation of gases other than hydrogen were not considered. The generation of other gases will increase the pressure and result in a greater leakage rate with additional loss of hydrogen. The resulting pressure will be similar to that calculated in the spreadsheet but the hydrogen concentration will be less. Therefore ignoring the generation of other gases is conservative. The leakage of air is ignored because if the air concentration gets too low, air will diffuse into the waste box from the outside. It is judged that this process will keep the air concentration relatively constant. Because this may be a non-conservative assumption, a control to sample the atmosphere of some waste boxes will be specified to determine if this is, indeed, the case.

To assess the effect of not including air out-leakage in the spreadsheet described below, the spreadsheet described below was modified to account for the air, as well as hydrogen, being forced out of the waste box during leakage. The result is essentially the same as that shown below for the base case as not much air is forced out.

The spreadsheet provides the conditions shown in Tables 5, Hydrogen Concentration from 50 DE-Ci from Alpha Emitters, Table 6, Hydrogen Concentration from 26 DE-Ci from Alpha Emitters and Table 7, Hydrogen Concentration-Miscellaneous Cases that Result in a Hydrogen Concentration of $4 \%$ or Less after 20 years. In the tables to follow the Base Case has a value for $\mathrm{G}\left(\mathrm{H}_{2}\right)$ of 0.5 and leakage of $1.7 \mathrm{~cm}^{3} / \mathrm{min}$ at $5 \mathrm{psig}$. The base case of Table 5 is also run at 40 years and assuming a larger size box (See Note to Table 5). The note to Table 5 shows that the same peak pressure and concentration occur within a larger waste box, but at a greater period of time than is the case for the base case waste box. 
HNF-22524, Rev. 1

Table 5. Hydrogen Concentration From 50 DE-Ci From Alpha Emitters

\begin{tabular}{|c|c|c|c|c|c|}
\hline Case & $\mathbf{G}\left(\mathbf{H}_{2}\right)$ & $\begin{array}{l}\text { Basis for } \\
\text { Leakage }\end{array}$ & $\begin{array}{l}\text { Fraction of } \\
\text { energy into } \\
\text { waste }\end{array}$ & $\begin{array}{c}\mathrm{H}_{2} \\
\text { Concentration, } \\
\% \mathrm{H}_{2} \text { in air in } \\
\text { volume after } 20 \\
\text { years } \\
\end{array}$ & $\begin{array}{c}\text { Pressure, } \\
\text { psig }\end{array}$ \\
\hline Base Case & 0.5 & $\begin{array}{c}1.7 \mathrm{cc} / \mathrm{min} @ \\
5 \mathrm{psig}\end{array}$ & 0.5 & $\begin{array}{c}7.2 \\
\text { (Note 1) }\end{array}$ & $\begin{array}{c}1.1 \\
\text { (Note 1) }\end{array}$ \\
\hline $\begin{array}{l}\text { Base Case with } \\
\text { Waste Box having the } \\
\text { same volume as a } \\
\text { drum (to check } \\
\text { method) }\end{array}$ & 0.5 & $\begin{array}{c}1.7 \mathrm{cc} / \mathrm{min} @ \\
5 \mathrm{psig}\end{array}$ & 0.5 & 14.5 & 2.5 \\
\hline $\begin{array}{l}\text { Base Case with } \mathrm{G}\left(\mathrm{H}_{2}\right) \\
=0.3\end{array}$ & 0.3 & $\begin{array}{c}1.7 \mathrm{cc} / \mathrm{min} @ \\
5 \mathrm{psig}\end{array}$ & 0.5 & 5.1 & 0.8 \\
\hline $\begin{array}{l}\text { Base Case with } \mathrm{G}\left(\mathrm{H}_{2}\right) \\
=0.3 \text { and increased } \\
\text { leakage }\end{array}$ & 0.3 & $\begin{array}{c}4 \mathrm{cc} / \mathrm{min} @ 5 \\
\mathrm{psig}\end{array}$ & 0.5 & 2.9 & 0.4 \\
\hline $\begin{array}{l}\text { Base Case. } \\
\text { Permeability } \\
\text { increased a factor of } \\
100\end{array}$ & 0.5 & $\begin{array}{c}1.7 \mathrm{cc} / \mathrm{min} @ \\
5 \mathrm{psig}\end{array}$ & 0.5 & 7.2 & 1.1 \\
\hline $\begin{array}{l}\text { Base Case. Gasket } \\
\text { dimensions increased } \\
\text { a factor of } 4\end{array}$ & 0.5 & $\begin{array}{c}1.7 \mathrm{cc} / \mathrm{min} @ \\
5 \mathrm{psig}\end{array}$ & 0.5 & 7.2 & 1.1 \\
\hline $\begin{array}{l}\text { Base Case with No } \\
\text { Leakage }\end{array}$ & 0.5 & $0 \mathrm{cc} / \mathrm{min} @ 5 \mathrm{psig}$ & 0.5 & 32.3 & 7 \\
\hline $\begin{array}{l}\text { Base Case with } 5 \mathrm{x} \\
\text { Leakage }\end{array}$ & 0.5 & $\begin{array}{c}8.5 \mathrm{cc} / \mathrm{min} @ \\
5 \mathrm{psig}\end{array}$ & 0.5 & 2.5 & 0.4 \\
\hline
\end{tabular}


HNF-22524, Rev. 1

Table 6. Hydrogen Concentration From 26 DE-Ci From Alpha Emitters

\begin{tabular}{|l|c|c|c|c|c|}
\hline Case & $\mathbf{G}\left(\mathbf{H}_{2}\right)$ & $\begin{array}{c}\text { Basis for } \\
\text { Leakage }\end{array}$ & $\begin{array}{c}\text { Fraction of } \\
\text { energy into } \\
\text { waste }\end{array}$ & $\begin{array}{c}\mathbf{H}_{2} \\
\text { Concentration, } \\
\mathbf{\% H}_{2} \text { in air in } \\
\text { volume after 20 } \\
\text { years }\end{array}$ & $\begin{array}{c}\text { Pressure, } \\
\text { psig }\end{array}$ \\
\hline Base Case & 0.5 & $\begin{array}{c}1.7 \mathrm{cc} / \mathrm{min} @ \\
5 \mathrm{psig}\end{array}$ & 0.5 & 4.7 & 0.7 \\
\hline $\begin{array}{l}\text { Base Case with 5 } \mathrm{x} \\
\text { Leakage }\end{array}$ & 0.5 & $\begin{array}{c}8.5 \mathrm{cc} / \mathrm{min} @ \\
5 \mathrm{psig}\end{array}$ & 0.5 & 1.6 & 0.2 \\
\hline $\begin{array}{l}\text { Base Case with no } \\
\text { Leakage }\end{array}$ & 0.5 & $\begin{array}{c}0.0 \mathrm{cc} / \mathrm{min} @ \\
5 \mathrm{psig}\end{array}$ & 0.5 & 18.4 & 3.3 \\
\hline
\end{tabular}

Table 7. Hydrogen Concentration - Miscellaneous Cases that Result in a Hydrogen Concentration of $4 \%$ or Less

\begin{tabular}{|c|c|c|c|c|c|}
\hline Case & $\mathbf{G}\left(\mathbf{H}_{2}\right)$ & $\begin{array}{l}\text { Basis for } \\
\text { Leakage }\end{array}$ & $\begin{array}{l}\text { Fraction of } \\
\text { energy into } \\
\text { waste }\end{array}$ & $\begin{array}{c}\mathrm{H}_{2} \\
\text { Concentration, } \\
\% \mathrm{H}_{2} \text { in air in } \\
\text { volume after } 20 \\
\text { years } \\
\end{array}$ & $\begin{array}{c}\text { Pressure, } \\
\text { psig }\end{array}$ \\
\hline $\begin{array}{l}\text { Base Case with } 5 \\
\text { DE-Ci with no } \\
\text { leakage }\end{array}$ & 0.5 & $\begin{array}{c}0.0 \mathrm{cc} / \mathrm{min} @ \\
5 \mathrm{psig}\end{array}$ & 0.5 & 3.8 & $0 . \overline{6}$ \\
\hline $\begin{array}{l}\text { Base Case with base } \\
\text { case leakage and } 20 \\
\text { DE-Ci }\end{array}$ & 0.5 & $\begin{array}{c}1.7 \mathrm{cc} / \mathrm{min} @ \\
5 \mathrm{psig}\end{array}$ & 0.5 & 3.9 & 0.6 \\
\hline $\begin{array}{l}\text { Base case with } 5 \times \\
\text { leakage and } 100 \\
\text { DE-Ci }\end{array}$ & 0.5 & $\begin{array}{c}8.5 \mathrm{cc} / \mathrm{min} @ \\
5 \mathrm{psig}\end{array}$ & 0.5 & 3.9 & 0.6 \\
\hline $\begin{array}{l}\text { Base Case with } 79.4 \\
\text { DE-Ci }\end{array}$ & 0.5 & $7 \mathrm{cc} / \mathrm{min} @ 5 \mathrm{psig}$ & 0.5 & 3.9 & 0.6 \\
\hline $\begin{array}{l}\text { Base case with } \mathrm{G}\left(\mathrm{H}_{2}\right) \\
=0.2\end{array}$ & 0.2 & $\begin{array}{c}1.7 \mathrm{cc} / \mathrm{min} @ \\
5 \mathrm{psig}\end{array}$ & 0.5 & 4.0 & 0.6 \\
\hline
\end{tabular}

Table 7 shows that there is a combination of curies, leakage rates, value of $\mathrm{G}\left(\mathrm{H}_{2}\right)$, and generation rate depletion constant that results in a peak hydrogen concentration of $4 \%$ at a peak pressure of around $0.6 \mathrm{psig}$. Other combinations can be chosen to result in different peak concentrations and pressure.

The peak pressure and concentration for VOCs would be less of those presented in Tables $5-7$ for hydrogen. This is because the generation rate for VOCs is $10^{-8} \mathrm{moles} / \mathrm{s}$ (from Section 4.8.2) not $4 \times 10^{-8}$ moles/s (from Step 1 above). The permeability of gaskets to VOCs is likely less than that for hydrogen. However, the contribution of this term is negligible even for hydrogen diffusion. 
As an example, if the spreadsheet is modified to calculate pressure and concentration for VOCs by reducing the generation rate by a factor of 4 for the base case in Table 5 (done by reducing the $\mathrm{DE}-\mathrm{Ci}$ to 12.5 from 50 ), the peak pressure is $0.44 \mathrm{psig}$ (as compared to $1.1 \mathrm{psig}$ for hydrogen). The concentration is $2.9 \%$ as compared to $7.2 \%$ for hydrogen.

\subsubsection{Lid Deflection}

Now consider what a 0.6 to 7 psig pressure differential in the waste box will do to the lid. First consider the lid as a clamped rectangular plate. The deflection in the lid is found from Roark's Formulas for Stress and Strain (1989), Table 26, Case 8. The deflection (denoted as "y" in the reference) is found from

$$
\mathrm{y}=\frac{\alpha q b^{4}}{E t^{3}}
$$

Where $\alpha=0.0188$ for a plate that is 62 in. by 52 in (ratio is 1.2)

$$
\begin{aligned}
\mathrm{q} & =\text { pressure, psig } \\
\mathrm{b} & =\text { length of the short side, in. } \\
& =52 \text { in } \\
\mathrm{E} & =\text { modulus of elasticity, psi } \\
& =28 \times 10^{6} \text { for steel } \\
\mathrm{t} & =\text { thickness of plate, in. } \\
& =0.375 \text { in. per H-2-74608, Item } 4 .
\end{aligned}
$$

Solving for "y" yields

$\begin{array}{ccc}\text { q } & y & \text { fraction } \mathrm{H}_{2} \text { in air } \\ 0.6 \text { psig } & 0.05 \text { in. } & 0.04 \\ 1 \text { psig } & 0.09 \text { in. } & 0.06 \\ 2 \text { psig } & 0.19 \text { in. } & 0.11 \\ 3 \text { psig } & 0.28 \text { in. } & 0.16 \\ 7 \text { psig } & 0.65 \text { in. } & 0.32\end{array}$

This deflection will be spread over the 4 side walls and 2 ends. The deflection will be a little less as a result. In addition the steel channels that are welded to the plate will limit the deflection even more. The result is that even at pressures as high as $7 \mathrm{psig}$, one might not be able to detect the bulge in the box. If the waste box sides are 120 inches not 52, the deflection at $7 \mathrm{psig}$ is 18.5 inches. This deflection would be detectable. At $0.6 \mathrm{psig}$, the deflection in the base case waste box is 1.4 inches.

If oxygen depletion occurs, it is usually accompanied by the generation of another gas (such as $\mathrm{CO}_{2}$ ). Given these conditions, the box pressure would be about the same as a waste box that had no oxygen depletion. LA-7674-MS (1979), Figures 10 through 13 shows oxygen depletion with no other gas present for the case where polyethylene is irradiated. In the other 
three cases, $\mathrm{CO}_{2}$ is generated. DP-1604 (1982), Figures 1 through 4 and 5 through 8 show oxygen depletion but also show cases where the $\mathrm{CO}_{2}$ concentration is much less than the initial oxygen concentration (Figures 1 and 2) and two cases where it is about the same. As a result the deflection might not be as great as that predicted above. The only other concern is if the waste can deform. If the waste can deform, then it is possible that as the pressure increases, some of the deformation that the lid might experience is taken up as waste deformation. Therefore, the lid is not deformed as much. Waste material such as metals, wood, cement, glass, etc., will not deform at these low pressures. Waste materials such as paper and rags can deform but will not as the gases surround them. There may be some enclosed volumes present within the waste that could deform, but it is expected that these will not significantly affect the deformation of the lid. However, the above shows that deflection is a useful parameter to use as a control.

However, the waste boxes do have stiffeners in the form of 3 -inch angle iron every 16 inches all around. Therefore the deflection will be less. As a result, the deflection will not be easily measurable in the base case metal waste boxes, but could be in the larger ones.

\subsection{LEAKAGE AND DIFFUSION OUT A NON-PRESSURIZED WASTE BOX}

A review of the box types listed in Appendix A was made in October, 2004, to determine the gasket configuration. It was determined that all of these boxes, except SB83121.B, and WH82-058, had multiple piece gaskets that were normally glued in place. Reference is made to the following drawings, H-2-35001, Transuranic Dry Waste Burial Box Type 1 \& 2, H-2-72560, Transuranic Dry Waste Burial Box Type I, H-2-74561, Transuranic Dry Waste Burial Box Tvpe II, H-2-74608, Transuranic Dry Waste Burial Box 8'X9'X12', H-2-74714, Transuranic Dry Waste Burial Box, and H-2-91888, 7'- $0^{\prime \prime} X 6^{\prime}-0^{\prime \prime}$ Steel Corrugated Box Assembly. The gaskets are neoprene and are typically placed in 4 pieces so the corners are the weak points. As a result, there may be cases in which the opening in the gasket could be larger than that in Section 4.7 (0.0019 inches). The mechanism for hydrogen and VOC transport in these conditions would be diffusion and atmospheric breathing. Pressure induced flow (other than atmospheric breathing) would not be a significant factor as the pressure drop between the inside and outside of the waste box is very small. Diffusion will be addressed first.

Flow through an opening in the gasket will be modeled using the methodology in HNF-16166 (2007), Required Staging Times for Hydrogen Diffusion in Vented Waste Containers. The opening will be modeled as a filter.

Flow through the filters is taken from the first paper in PNNL-11212 (1996), Hydrogen and Oxygen Concentrations in IXCs: A Compilation. The first paper is entitled Estimate of Hydrogen Concentration in $K W-14$ (1995). Page 3 of that paper provides the equation that must be solved to obtain the hydrogen concentration in the volume as a function of time. The equation is:

$$
\mathrm{V}_{\mathrm{h}} \frac{d C_{h}}{d t}=-C_{h} Q_{h}-Q_{h}
$$


Where: $\quad V_{\mathrm{h}}=$ Volume of drum filled with hydrogen-air mixture, $\mathrm{L}$

$=1564 \mathrm{~L}$ based on a $1 / 2$ filled waste box

$\mathrm{C}_{\mathrm{h}}=$ Concentration of hydrogen in the box, moles $/ \mathrm{L}$

$\mathrm{Q}_{\mathrm{b}}=$ flow rate due to atmospheric breathing, $\mathrm{L} / \mathrm{s}$

$\mathrm{Q}_{\mathrm{h}}=$ Diffusion flow of hydrogen out of the drum, moles $/ \mathrm{s}$

Section 3.1 of the first paper in PNNL-11212 (1996) shows that the diffusion flow of hydrogen out of the filter can be obtained from:

$$
\mathrm{Q}_{\mathrm{h}}=\mathrm{C}_{\mathrm{h}} / \mathrm{R}
$$

Where: $\quad \mathrm{R}=$ effective resistance to diffusion flow.

Substituting

- $\mathrm{M}=\mathrm{V}_{\mathrm{h}} \mathrm{C}_{\mathrm{h}}$

- $\mathrm{Q}_{\mathrm{h}}=\mathrm{C}_{\mathrm{h}} / \mathrm{R}=\mathrm{M} / \mathrm{VR}$

- $\mathrm{Q}_{\mathrm{b}}=0$

- the generation rate, $\mathrm{G}$

- the leakage rate $\mathrm{V}_{\text {out }} \mathrm{M} / \mathrm{V}$ (See Section 4.8.1)

- the breathing rate, $\mathrm{Q}_{\mathrm{b}} \mathrm{M}$

yields

$$
\frac{d M}{d t}=G-\frac{M}{V R}-\frac{V_{o u t} M}{V}-Q_{b} M
$$

Let

$$
a=\frac{1}{V R}+\frac{V_{o u t}}{V}+Q_{b}
$$

then

$$
\frac{d M}{d t}=G-a M
$$

The equation can be rearranged to yield

$$
\frac{d M}{d t}+a M=G
$$

Where a, G are constants.

Using 


$$
U=M e^{a t}
$$

Differentiating the equation for $U$ yields

$$
e^{-a t} \frac{d U}{d t}=G
$$

Solving for $\mathrm{U}$, substituting back for $\mathrm{M}$ and evaluating the constant based on the assumption that at $\mathrm{t}=0, \mathrm{M}=\mathrm{M}_{\mathrm{o}}$ yields

$$
M=\frac{G}{a}\left(1-e^{-a t}\right)+M_{o} e^{-a t}
$$

\subsubsection{Hydrogen Diffusion}

The value of " $R$ " is determined in Section 5.1.1 of WHC-SD-SNF-SARR-003 (1994), Hydrogen Production in the K-Basin Ion Exchange Columns, Modules, and Cartridge Filters and Appendix C of HNF-16166 (2007). A heat transfer analogy is used in which diffusion flow is shown to be similar to heat flow. For one dimension flow, $q=\Delta T / R$, where $R=x / L A$. In the diffusion flow case, $\mathrm{R}=\mathrm{x} / \mathrm{DA}$, where $\mathrm{D}$ is the diffusion coefficient, and $\mathrm{A}$ is the flow area.

The resistance was calculated assuming that the diffusion coefficient for hydrogen in air is $0.75 \mathrm{~cm}^{2} / \mathrm{s}$ (per Appendix C of HNF-16166, 2007). The areas and lengths (the values of " $\mathrm{x}$ ") from the gap in the gasket are assumed to be as follows:

$\mathrm{x}=$ length of flow path $=1.27 \mathrm{~cm}$ in this case (the width of the gasket)

Width of flow path (assumed to be of square cross-section) $=0.159 \mathrm{~cm}(1 / 16 \mathrm{inch})$

$\mathrm{A}=$ area of flow $=0.159 \mathrm{~cm}$ long $* 0.159 \mathrm{~cm}$ wide $=0.025 \mathrm{~cm}^{2}$

$\mathrm{D}=0.75 \mathrm{~cm}^{2} / \mathrm{s}$

Solving for $\mathrm{R}=\mathrm{x} / \mathrm{AD}$ yields $67 \mathrm{~s} / \mathrm{cm}^{3}$ or $67,000 \mathrm{~s} / \mathrm{L}$ for " $\mathrm{R}$ ".

There are 4 gaps in the waste box (a gap at each corner), so the resistance is $1 / 4$ of that calculated above. This is based on Appendix G of HNF-16166 (2007) which states that for filters in parallel,

$$
\frac{1}{R_{e f f}}=\frac{1}{R_{1}}+\frac{1}{R_{2}}
$$

or if $\mathrm{R}_{1}=\mathrm{R}_{2}, \mathrm{R}_{\mathrm{eff}}=\mathrm{R}_{1} / 2$.

Since, there are 4 flow paths, one out each corner of the waste box, the term 


$$
\frac{M}{V R}=\frac{4 M}{V R}
$$

Section 5.1.2 of WHC-SD-SNF-SARR-003 (1994) shows that the average atmospheric breathing rate, in terms of the rate of change of volume divided by the volume is $3.8 \times 10^{-4} / \mathrm{hr}$. However, since the waste box is buried, breathing is neglected.

The case where the waste box was buried and then retrieved or when it was never buried is presented in Section 4.8.2.

The generation rate must be added. Section 4.7.1, item 1 shows a generation rate of $4 \mathrm{x}$ $10^{-8}$ moles $/ \mathrm{s}$.

Now it is possible to solve for $\mathrm{M}$ using the equation from Section 4.8.

$$
M=\frac{G}{a}\left(1 e^{-a t}\right)+M_{,} e^{-a t}
$$

There are no moles of hydrogen initially, so $\mathrm{M}_{0}=0$.

The equation is then:

$$
M=\frac{4 \times 10^{-8}}{a}\left(1-e^{-a t}\right)
$$

Where $a=\frac{4}{V(67000)}+\frac{V_{o m}}{V}$

$$
\mathrm{V}=1564 \mathrm{~L} \text {. }
$$

The flow out due to leakage is equal to the volumetric generation rate. That is

$$
\begin{aligned}
& \mathrm{V}_{\text {out }}=\text { Flow rate out }=(\text { generation rate }, \text { moles } / \mathrm{s})(24.4 \mathrm{~L} / \mathrm{mole}) \\
& =10^{-6} \mathrm{~L} / \mathrm{s}
\end{aligned}
$$

For a generation rate $4 \times 10^{-8}$ moles $/ \mathrm{s}$, using the ideal gas law with a pressure of $1 \mathrm{~atm}$ and $298 \mathrm{~K}$, the corresponding volumetric flow is $10^{-6} \mathrm{~L} / \mathrm{s}$ or $2 \times 10^{-6} \mathrm{ft}^{3} / \mathrm{min}$. If the gap in the gasket is assumed to be 0.063 inches ( $1 / 16$ inch) on a side (square cross-section) and 0.5 inches long, the pressure necessary to force that flow is $3 \times 10^{-7} \mathrm{psig}$. The result was obtained using the equation and data in Section 4.7.1, item 8 with

$$
\begin{aligned}
& \mathrm{q}=2 \times 10^{-6} \mathrm{ft}^{3} / \mathrm{min} \\
& \mathrm{d}=0.063 \mathrm{in} . \\
& \rho_{1}=0.074 \mathrm{lb} / \mathrm{ft}^{3} \text { (from Section } 4.7 .1 \text { ) } \\
& S_{g}=1.0(\text { from Section } 4.7 .1)
\end{aligned}
$$


$\mathrm{L}=0.5 \mathrm{in}$.

$\mathrm{V}=1.2 \times 10^{-3} \mathrm{ft} / \mathrm{s}$

$\mu=0.018$ centipoise (from Section 4.7.1)

$\mathrm{f}=1684$ based on an $\operatorname{Re}$ of 0.04

$\mathrm{K}=13,400$

If the gasket gap were 0.01 inches on a side, the pressure necessary to move $4 \times 10^{-8} \mathrm{moles} / \mathrm{s}$ is $5 \times 10^{-4} \mathrm{psig}$ based on

$$
\begin{aligned}
& \mathrm{d}=0.01 \mathrm{in} . \\
& \mathrm{V}=0.048 \mathrm{ft} / \mathrm{s} \\
& \operatorname{Re}=0.24 \\
& \mathrm{f}=262 \\
& \mathrm{~K}=13,100
\end{aligned}
$$

As a result, the flow out equals the generation rate with no pressurization.

The numerical value of "a" is $4 \times 10^{-8}$ (rounded to 1 significant figure). Solving the equation with $\mathrm{t}=40$ years yields a value for " $\mathrm{M}$ " of 1.0 moles (or $1.5 \%$ ). For the waste box that is 10 times larger, " $\mathrm{M}$ " is 10 moles, but the volume fraction remains $1.5 \%$ as, in both cases, steady state is reached prior to 40 years. The size of the waste box does not affect the result.

If the width of the gap is $1 / 8$-inch, the hydrogen concentration is $0.4 \%$. If the width of the gap is 0.25 inches, the hydrogen concentration is $0.1 \%$

\subsubsection{VOC Diffusion}

The equations above will now be solved for VOC diffusion.

\section{$\underline{\text { Resistance }}$}

The resistance term " $R$ " is determined in the same way that it was for hydrogen. The only exception is that the diffusion coefficient is $0.07 \mathrm{~cm}^{2} / \mathrm{s}$. This value is based on cyclohexane in nitrogen and is the smallest of those in Section 2.1 of HNF-25634 (2006), Potential for a Volatile Organic Compound (VOC) Deflagration in a TRU Drum. This value is also lower than the diffusion coefficient for VOCs found in relatively large concentrations in Hanford waste containers shown in HNF-25634 (2006). A lower diffusion coefficient is used to cover the case where VOCs other than those in HNF-25634 (2006) are identified at a later date or where the diffusion coefficient for the same VOC found in a different reference is smaller. Using a diffusion coefficient of $0.07 \mathrm{~cm}^{2} / \mathrm{s}$, the resistance is $718,000 \mathrm{~s} / \mathrm{L}$, not $67,000 \mathrm{~s} / \mathrm{L}$, for an opening in the gasket that is $1.27 \mathrm{~cm}$ long and $0.159 \mathrm{~cm}$ wide.

There are 4 gaps in the waste box (a gap at each corner). Therefore the effective resistance per Section 4.8.1 is:

$$
R_{\text {eff }}=(718,000 \mathrm{~s} / \mathrm{L}) / 4=179,500 \mathrm{~s} / \mathrm{L}
$$




\section{Generation Rate}

The generation rate of VOCs in metal waste boxes is not known. Typically waste boxes contain large items like pieces of metal equipment. The equipment may have been cleaned using VOCs or contained VOCs as part of the process or operation. However, by the time the piece was placed into the waste box, much of the VOC could have evaporated. Waste drums with high concentrations of VOCs typically contain rags and other cleaning materials used in cleaning and, in some cases, some of the cleaning fluid itself (assumed to be in the bottles and containers seen in X-rays of some drums). A reasonable, bounding estimate for VOCs in waste boxes is that found in HNF-25634 (2006), Section 2.1 and 2.5. These sections show a generation rate of $10^{-8}$ moles/s for a drum having a very high initial VOC concentration $(8800 \mathrm{ppm})$, which is indicative of a large quantity of waste contaminated with VOCs. This should be a reasonable estimate for waste boxes which are 7 times larger than drums but typically have less VOC contaminated waste in them. A sensitivity analysis will be performed on this value.

\section{Breathing}

As in Section 4.8.1, atmospheric breathing is neglected because the waste boxes are buried.

\subsubsection{VOC Concentration after 40 Years of Burial (Prior to Retrieval)}

The waste box is generating and releasing VOCs throughout its storage life. Assume the waste box was stored underground for 40 years.

Section 4.8 shows

$$
\frac{d M}{d t}=\frac{G}{a}\left(1-e^{-a t}\right)
$$

Using a resistance of $179,500 \mathrm{~s} / \mathrm{L}$, a generation rate of $10^{-8} \mathrm{moles} / \mathrm{s}$, the value of " $\mathrm{a}$ " is:

$$
\begin{aligned}
& a=\frac{1}{V(179,500)}+\frac{V_{o m t}}{V}=3.6 \times 10^{-9}+1.6 \times 10^{-10}=3.8 \times 10^{-9} \\
& \text { Where } \quad V_{o u t}=2.44 \times 10^{-7} \mathrm{~L} / \mathrm{s} \\
& \qquad V=1564 \mathrm{~L}
\end{aligned}
$$

Solving for "M" yields:

$$
M=\frac{10^{-8}}{a}\left(1-e^{-a r}\right)
$$


For $\mathrm{t}=40$ years, $\mathrm{M}=2.7$ moles or $4.2 \%$ using the ideal gas law with $\mathrm{T}=298 \mathrm{~K}$. If the waste box volume were ten times larger, $\mathrm{M}=9.7$ moles. The volume concentration is $1.5 \%$. The base case waste box provides the worst case condition.

The results of the sensitivity analysis are shown below. In the calculations that follow, $\mathrm{V}=1564 \mathrm{~L}$ and the diffusion coefficient is $0.07 \mathrm{~cm}^{2} / \mathrm{s}$. A generation rate of $10^{-9} \mathrm{moles} / \mathrm{s}$ is chosen as a more reasonable generation rate for waste boxes with little VOC generating material inside. A gap length of 0.5 inch and 0.75 inch is chosen for the analysis. The ledge on which the gasket is placed is 1.5 inches long. Gasket sizes of 0.5 and 0.75 inch appear to be reasonable choices of final gasket length. 
HNF-22524, Rev. 1

Table 8. Concentration of VOCs in Waste Boxes

\begin{tabular}{|c|c|c|c|c|c|c|c|}
\hline \multirow[b]{2}{*}{$\begin{array}{c}\text { VOC } \\
\text { Generation } \\
\text { rate in waste } \\
\text { box "G", } \\
\text { moles/s }\end{array}$} & \multicolumn{2}{|c|}{ Diffusion Path Data } & \multirow{2}{*}{$\begin{array}{l}\text { No. of } \\
\text { flow } \\
\text { paths }\end{array}$} & \multirow{2}{*}{$\begin{array}{c}\text { Resistance, } \\
\text { s/L }\end{array}$} & \multirow[b]{2}{*}{$\begin{array}{c}\text { Moles of } \\
\text { VOC in } \\
\text { waste box } \\
\text { "M", } \\
\text { moles }\end{array}$} & \multirow[b]{2}{*}{$\begin{array}{c}\text { Conc. of } \\
\text { VOC in } \\
\text { waste box } \\
\text { "C", } \\
\% \\
\end{array}$} & \multirow{2}{*}{$\begin{array}{c}\text { Number of } \\
\text { flow paths } \\
\text { necessary to } \\
\text { stay below } \\
1 \% \text { (Note } 1 \text { ) }\end{array}$} \\
\hline & $\begin{array}{l}\text { Width, } \\
\text { cm }\end{array}$ & Length, $\mathrm{cm}$ & & & & & \\
\hline $10^{-8}$ & $\begin{array}{c}0.159 \\
\text { (1/16 inch) }\end{array}$ & $\begin{array}{c}1.27 \\
(0.5 \text { inch })\end{array}$ & 4 & 179,410 & 2.7 & 4.2 & 18 \\
\hline $10^{-9}$ & $\begin{array}{c}0.159 \\
(1 / 16 \text { inch) }\end{array}$ & $\begin{array}{c}1.27 \\
(0.5 \text { inch })\end{array}$ & 4 & 179,410 & 0.28 & 0.43 & $<4$ \\
\hline $10^{-8}$ & $\begin{array}{c}0.159 \\
(1 / 16 \text { inch })\end{array}$ & $\begin{array}{c}1.905 \\
(0.75 \text { inch })\end{array}$ & 4 & 269,120 & 3.79 & 5.9 & 26 \\
\hline $10^{-9}$ & $\begin{array}{c}0.159 \\
\text { (1/16 inch) }\end{array}$ & $\begin{array}{c}1.905 \\
(0.75 \text { inch })\end{array}$ & 4 & 269,120 & 0.40 & 0.6 & $<4$ \\
\hline $10^{-8}$ & $\begin{array}{c}0.0794(1 / 32 \\
\text { inch) }\end{array}$ & $\begin{array}{c}1.27 \\
(0.5 \text { inch })\end{array}$ & 4 & 719,460 & 7.01 & 11.0 & 70 \\
\hline $10^{-9}$ & $\begin{array}{c}0.0794 \\
(1 / 32 \text { inch })\end{array}$ & $\begin{array}{c}1.27 \\
(0.5 \mathrm{inch})\end{array}$ & 4 & 719,460 & 0.79 & 1.2 & 6 \\
\hline $10^{-8}$ & $\begin{array}{l}0.0794(1 / 32 \\
\text { inch) }\end{array}$ & $\begin{array}{c}1.905 \\
(0.75 \text { inch })\end{array}$ & 4 & $1,079,200$ & 8.17 & 12.8 & 105 \\
\hline $10^{-9}$ & $\begin{array}{c}0.0794 \\
(1 / 32 \text { inch })\end{array}$ & $\begin{array}{c}1.905 \\
(0.75 \text { inch }) \\
\end{array}$ & 4 & $1,079,200$ & 0.88 & 1.4 & 9 \\
\hline \multicolumn{8}{|c|}{$\begin{array}{l}\text { Table } 1 \text { of HNF-25634 shows the lower flammable limits (LFL) for VOCs identified in waste drums. The LFLs } \\
\text { range from }\end{array}$} \\
\hline \multicolumn{8}{|c|}{$\begin{array}{l}\text { Table } 3 \text { and } 4 \text { of HNF-25634 show the VOCs in the drums having high VOC concentrations. These VOCs and } \\
\text { their LFL, are shown below }\end{array}$} \\
\hline $\begin{array}{l}\text { acetone } \\
\text { xylene } \\
\text { methyle } \\
\text { toluene } \\
\text { methyl } \\
\text { trichlor } \\
\text { carbon } \\
\text { methyl }\end{array}$ & $\begin{array}{l}\qquad \text { VOC } \\
\text { e chloride } \\
\text { sobutyl ketone } \\
\text { ethane } \\
\text { trachloride } \\
\text { thyl ketone }\end{array}$ & Not fl & $\begin{array}{l}5 \\
2 \\
3 \\
\text { amable }\end{array}$ & Diffusion $\mathrm{C}$ & $\begin{array}{l}\text { fficient, } \mathrm{cm}^{2} / \\
12 \\
99 \\
97 \\
93 \\
98\end{array}$ & & \\
\hline
\end{tabular}

Table 8 shows VOC concentrations after 40 years of accumulation from $4.2 \%$ to $12.8 \%$ for cases having a generation rate of $10^{-8} \mathrm{moles} / \mathrm{s}$.

If the width of the gap is $1 / 8$-inch, the VOC concentration in the base case (generation rate of $1 \times 10^{-8}$ moles $/ \mathrm{s}$, gap length of 0.5 inches and waste box free volume of $1564 \mathrm{~L}$ ) is $1.1 \%$. If the width of the gap is 0.25 inches, the VOC concentration is $0.3 \%$ 
However, VOCs have a maximum vapor pressure, called the saturation pressure, at locations above the liquid from which it evaporated. The peak concentration of the VOC vapor will be obtained using the saturation pressure. Table 2 of HNF-25634 shows the following saturation vapor pressure at $50{ }^{\circ} \mathrm{F}(283 \mathrm{~K}$ - a typical underground temperature). Table 8 above shows that the following VOCs are the ones that have been identified in high concentrations in waste drums.

\begin{tabular}{lcc}
\multicolumn{1}{c}{ VOC } & $\begin{array}{c}\text { Vapor pressure at } \\
283 \mathrm{~K}\left(50^{\circ} \mathrm{F}\right), \text { bar }\end{array}$ & $\begin{array}{c}\text { Corresponding Volume } \\
\text { Percent (Note 1) }\end{array}$ \\
acetone & 0.154 & 14 \\
xylene & 0.004 & 0.4 \\
toluene & 0.0167 & 1.6 \\
methyl ethyl ketone & 0.057 & 5.6 \\
trichloroethane & 0.086 & 8.5 \\
methyl isobutyl ketone & 0.0106 & 1.0 \\
Note 1: volume percent $=($ Vapor Pressure in units of bar/1.013) $* 100$
\end{tabular}

Xylene, toluene and methyl isobutyl ketone can not reach the calculated concentrations. Toluene will only reach $1.6 \%$ by volume but that is above its LFL. It is also noted that for the cases of $10^{-8} \mathrm{moles} / \mathrm{s}$ generation rate, a gap of $1 / 16$ inch and gasket width of $0.5 \mathrm{inch}$ and $0.75 \mathrm{inch}$, trichloroethane (as the VOC) can reach $4.2 \%$ and $5.9 \%$ respectively (as calculated) but is still below its LFL. As a result, only if the VOC is acetone or toluene, can the calculated concentrations shown in Table 8 be reached and the mixture is flammable.

Table 8 above shows that:

- For the conditions of the base case (generation rate of $10^{-8}$ moles/s, gap width of 1/16-inch, gap length of 0.5 inches and 4 gaps), the VOC concentration is above the LFL for most VOCs shown in HNF-25634 (2006).

However when taking into account the saturation vapor pressure at burial conditions $\left(50{ }^{\circ} \mathrm{F}\right)$ of those VOCs that have been identified as occurring in high concentration in waste drums, only acetone can reach the calculated concentrations of $4.2 \%$ and be flammable.

- The VOC concentration is below the LFL for all of the VOCs for the base case with a generation rate of $10^{-9} \mathrm{moles} / \mathrm{s}$.

- The VOC concentration is at or below the LFL for most of the VOCs for a gap of $1 / 32$ inch, a gap length of 0.5 inches and generation rate of $10^{-9} \mathrm{moles} / \mathrm{s}$ and is close to the LFL for a gap length of 0.75 inches.

- 105 gaps, each 1/32-inch square and 0.75 inches long are required to bring the concentration to the LFL for the worst case considered (generation rate is $1 \times 10^{-8}$ moles/s, gap width is $1 / 32$ inch and gap length is $0.75 \mathrm{inch}$ ). The perimeter of a waste box is $32 \mathrm{ft}$. 105 gaps is a gap 1/32-inch by $1 / 32$-inch every 3.6 inches. 


\subsubsection{VOC Concentration after Retrieval Following Burial}

After retrieval, the waste boxes can breathe. The equation for rate of change of the mass of VOC's is shown below.

$$
\frac{d M}{d t}=G-\frac{4 M}{V R}-\frac{M V_{\text {out }}}{V}-Q_{b} M
$$

$\mathrm{Q}_{\mathrm{b}} \mathrm{M}$ represents the removal of VOCs due to atmospheric pressure changes ("breathing"). Consideration was given to the effect of temperature swings on breathing. The average daily temperature swing is around $20^{\circ} \mathrm{F}$. However, what is important is the temperature swing within the waste box. The thick steel plates and attached channels which act as fins reduce the temperature changes within the waste box. To determine the effect of temperature change would require a computer model of the waste box, its waste, the atmospheric temperature change and the solar heating. The ability of the waste to absorb heat and the rate at which this heat is released is also important and would need to be modeled. Because of the complexity, this analysis was not performed in this paper.

It should be noted that a $2{ }^{\circ} \mathrm{F}$ temperature swing inside the waste box occurring over $12 \mathrm{hrs}$ (if increase, then $2^{\circ} \mathrm{F}$ decrease over $24 \mathrm{hrs}$ ) results in a change of 0.59 moles over $12 \mathrm{hrs}$ or a rate constant of $7.7 \times 10^{-4} / \mathrm{hr}$ or 4 times greater than that of breathing. This has the effect of lowering the time to the LFL by a factor of 4 .

For purposes of this calculation, $\mathrm{Q}_{b} \mathrm{M}$ will be that from atmospheric breathing only. The equation for $\mathrm{QbM}$ is:

$\mathrm{Q}_{\mathrm{b}}=\left(1.9 \times 10^{-4} / \mathrm{hr}\right)(\mathrm{hr} / 3600 \mathrm{~s}) \mathrm{M}=\left(5.28 \times 10^{-8}\right) \mathrm{M}$ where $1.9 \times 10^{-4} / \mathrm{hr}$ is taken from Appendix B of HNF-16166

Gathering terms yields $\frac{d M}{d t}=G-a M$

where "a" is

$$
a=\frac{4}{V R}+\frac{V_{o u t}}{V}+5.28 \times 10^{-8}
$$

The solution is

$$
M=\frac{G}{a}\left(1-e^{-a t}\right)+M_{\diamond} e^{-a l}
$$

If the waste box were never buried, then $\mathrm{M}_{0}$ is zero.

Consider the worst case in Table 8 
HNF-22524, Rev. 1

- $\mathrm{G}=10^{-8} \mathrm{moles} / \mathrm{s}$

- gap width $=1 / 32$ inch

- gap length $=0.75 \mathrm{in}$.

- number of gaps $=4$

- $\mathrm{M}_{0}=8.17$ moles

- concentration $=12.8 \%$

The concentration vs time after retrieval is

\begin{tabular}{cc} 
Time, days & Concentration, $\%$ \\
\cline { 1 - 2 } 0 & 12.8 \\
90 & 8.5 \\
180 & 5.7 \\
270 & 3.9 \\
360 & 2.6 \\
540 & 1.3 \\
720 & 0.7
\end{tabular}

retrieval.

Table 9, Concentration of VOCs in Waste Box after Retrieval presents the time to $1 \%$ after

Table 9. Concentration of VOCs in Waste Box After Retrieval

\begin{tabular}{|c|c|c|c|c|c|c|c|}
\hline \multirow[b]{2}{*}{$\begin{array}{c}\text { VOC } \\
\text { Generation } \\
\text { rate in } \\
\text { waste box } \\
\text { "G", } \\
\text { moles/s }\end{array}$} & \multicolumn{2}{|c|}{ Diffusion Path Data } & \multirow{2}{*}{$\begin{array}{l}\text { No. of } \\
\text { flow } \\
\text { paths }\end{array}$} & \multirow{2}{*}{$\begin{array}{c}\text { Resistance, } \\
\text { s/L } \\
\text { (rounded } \\
\text { up) }\end{array}$} & \multirow[b]{2}{*}{$\begin{array}{l}\text { Moles of } \\
\text { VOC in } \\
\text { waste } \\
\text { box } \\
\text { "M", } \\
\text { moles }\end{array}$} & \multirow[b]{2}{*}{$\begin{array}{c}\text { Conc. of } \\
\text { VOC in } \\
\text { waste } \\
\text { box } \\
\text { "C", } \\
\%\end{array}$} & \multirow{2}{*}{$\begin{array}{l}\text { Time to } \\
1 \%, \text { Days } \\
\text { after } \\
\text { retrieval }\end{array}$} \\
\hline & $\begin{array}{c}\text { Width, } \\
\text { cm }\end{array}$ & $\begin{array}{c}\text { Length, } \\
\text { cm }\end{array}$ & & & & & \\
\hline $10^{-8}$ & $\begin{array}{c}0.159 \\
\text { (1/16 inch) }\end{array}$ & $\begin{array}{c}1.27 \\
(0.5 \text { inch })\end{array}$ & 4 & 179,410 & 2.7 & 4.2 & 360 \\
\hline $10^{-9}$ & $\begin{array}{c}0.159 \\
(1 / 16 \text { inch })\end{array}$ & $\begin{array}{c}1.27 \\
(0.5 \text { inch })\end{array}$ & 4 & 179,410 & 0.28 & 0.44 & 0 \\
\hline $10^{-8}$ & $\begin{array}{c}0.159(1 / 16 \\
\text { inch })\end{array}$ & $\begin{array}{c}1.905 \\
(0.75 \mathrm{inch})\end{array}$ & 4 & 269,120 & 3.79 & 5.9 & 450 \\
\hline $10^{-9}$ & 0.159 & $\begin{array}{c}1.905 \\
(0.75 \mathrm{inch})\end{array}$ & 4 & 269,120 & 0.40 & 0.6 & 0 \\
\hline $10^{-8}$ & $\begin{array}{c}0.0794 \\
(1 / 32 \text { inch })\end{array}$ & $\begin{array}{c}1.27 \\
(0.5 \text { inch })\end{array}$ & 4 & 719,460 & 7.01 & 11.0 & $\sim 600$ \\
\hline $10^{-9}$ & $\begin{array}{c}0.0794 \\
(1 / 32 \text { inch })\end{array}$ & $\begin{array}{c}1.27 \\
(0.5 \mathrm{inch})\end{array}$ & 4 & 719,460 & 0.79 & 1.2 & 38 \\
\hline $10^{-8}$ & $\begin{array}{c}0.0794 \\
(1 / 32 \text { inch })\end{array}$ & $\begin{array}{c}1.905 \\
(0.75 \mathrm{inch})\end{array}$ & 4 & $1,079,200$ & 8.17 & 12.8 & 630 \\
\hline $10^{-9}$ & $\begin{array}{c}0.0794 \\
(1 / 32 \text { inch })\end{array}$ & $\begin{array}{c}1.905 \\
(0.75 \text { inch })\end{array}$ & 4 & $1,079,200$ & 0.88 & 1.4 & 73 \\
\hline
\end{tabular}




\subsubsection{VOC Concentration with No Burial}

Consider the case where the waste box was never buried. In this case, atmospheric breathing occurs throughout the time of interest.

Consider the worst case of Section 4.8.2.1.

- $\mathrm{M}_{\mathrm{o}}=0$

- $\mathrm{G}=10^{-8} \mathrm{moles} / \mathrm{s}$

- $\quad$ Gasket width $=1 / 32$ inch

- Gasket length $=0.75$ inch

- Number of gap $=4$

- "a" $=5.35 \times 10^{-8} \mathrm{sec}^{-1}$ (ignoring leakage due to generation, i.e., the " $\mathrm{V}_{\text {out }} / \mathrm{V}$ " term).

The results are

$\frac{\text { Time, days }}{0}$

360

720

1080
$\mathrm{M}$, moles

$\frac{\text { of VOC }}{0}$

0.15

0.18

0.19

\section{Concentration, \%}

0

0.24

0.28

0.29

\subsubsection{VOC Specific Analysis}

The analysis above was based on the worst case VOC. The worst case VOC was assumed to have a diffusivity of $0.07 \mathrm{~cm}^{2} / \mathrm{s}$, an LFL of $1 \%$ and a very high vapor pressure. That is, the saturation vapor pressure is such that the concentration can reach $12.8 \%$ for the case when the gaps are $1 / 32$ of an inch wide and 0.75 inch long with a generation rate of $10^{-8} \mathrm{moles} / \mathrm{s}$. Not all of these conditions are seen in those VOCs that have been found to exist in drums in high concentration. Take, for example, trichloroethane, HNF-25634, Section 2.1 shows that the diffusivity is $0.08 \mathrm{~cm}^{2} / \mathrm{s}$. Section 4.8 .2 .1 shows that the peak concentration based on saturated vapor pressure is $8.5 \%$. These are close to the worst case VOC conditions. However, the LFL is $6 \%$ not $1 \%$. So the time needed to bring the concentration to be below the LFL is less than that shown in Section 4.8.2.2.

The analysis in Sections 4.8.2.1 and 4.8.2.2 will be performed on a VOC specific basis for those VOCs that are identified as being present in high concentrations in drums (and therefore possibly present in high concentrations in waste boxes).

The VOCs of interest per Table 5 of HNF-25634 are:

acetone

trichloroethane 
HNF-22524, Rev. 1

xylene

toluene

methyl isobutyl ketone (MIBK)

methyl chlorine (chloromethane) methyl ethyl ketone (MEK)

ethyl benzene

dichloromethane

methanol

Table 10 presents the data:

Table 10. Data for the VOC's That Have Been Identified in High Concentrations in Drums

\begin{tabular}{|c|c|c|c|}
\hline VOC & $\begin{array}{c}\text { Diffusivity, } \\
\mathrm{cm}^{2} / \mathrm{s} \\
\end{array}$ & $\begin{array}{c}\text { Saturation Vapor } \\
\text { Pressure, } 283 \mathrm{~K} \\
\left(50^{\circ} \mathrm{F}\right) \text {, atm }\end{array}$ & $\begin{array}{c}\text { Peak Concentration, } \\
\text { Vol \% }^{(2)} \\
\end{array}$ \\
\hline acetone & 0.12 & 0.15 & 15 \\
\hline chloromethane & $0.13^{(\mathrm{I})}$ & gas & 100 \\
\hline dichloromethane & $0.10^{(I)}$ & 0.30 & 30 \\
\hline ethyl benzene & $0.066^{(1)}$ & 0.005 & 0.5 \\
\hline MEK & 0.11 & 0.56 & 5.6 \\
\hline methanol & $0.15^{(1)}$ & 0.072 & 7.2 \\
\hline MIBK & 0.09 & 0.010 & 1.0 \\
\hline trichloroethane & 0.08 & 0.085 & 8.5 \\
\hline toluene & 0.097 & 0.016 & 1.6 \\
\hline xylene & 0.09 & 0.0043 & 0.4 \\
\hline
\end{tabular}

Next, the calculation performed in Section 4.8.2.1 (concentration after 40 years of burial) is performed with the data in Table 10 for the case of

$1 / 32$ inch gaps

0.75 inch long gap

$10^{-8}$ moles/s generation rate.

The results are shown below. 
HNF-22524, Rev. 1

\begin{tabular}{cc}
$\begin{array}{c}\text { Calculated } \\
\begin{array}{c}\text { Concentration in } \\
\text { 40 yrs, Vol\% }\end{array}\end{array}$ & $\begin{array}{c}\text { Peak concentration using the } \\
\text { saturation (from Table 10) } \\
\text { vapor pressure, Vol\% }\end{array}$ \\
\hline 10.3 & 15 \\
9.9 & 100 \\
11.2 & 30 \\
13.0 & 0.5 \\
10.7 & 5.6 \\
9.2 & 7.2 \\
11.7 & 1.0 \\
12.2 & 8.5 \\
11.3 & 1.6 \\
11.7 & 0.4
\end{tabular}

Next, the calculation in Section 4.8.2.2 (concentration after retrieval following burial) is performed for the same case and same VOCs. For those VOCs that have a peak concentration limited by the saturation vapor pressure, the saturation vapor pressure is used as the concentration after 40 years, not the calculated concentration.

The results are:

\begin{tabular}{lccc}
\multicolumn{1}{c}{ VOC } & $\frac{\text { LFL }}{2.6}$ & $\begin{array}{c}\text { Concentration at } \\
\text { retrieval, Vol\% }\end{array}$ & $\begin{array}{c}\text { Time to get to LFL, } \\
\text { days }\end{array}$ \\
acetone & 8.1 & 10.3 & 510 \\
chloromethane & 15.5 & 11.2 & 0 (already below) \\
dichloromethane & 1.6 & 0.5 (at 1 year) & 0 (already below) \\
ethyl benzene & 1.8 & 5.6 (at 14.5 years) & 275 \\
MEK & 7.3 & 7.2 (at 24 years) & 0 (already below) \\
methanol & 1.3 & 1.0 (at 2 years) & 0 (already below) \\
MIBK & 6.0 & 8.5 (at 23 years) & 80 \\
trichloroethane & 1.2 & 1.6 (at 3.5 years) & 85 \\
toluene & 1.0 & 0.4 (at 1 year) & 0 (already below) \\
xylene & & &
\end{tabular}

Based on acetone, the waste box needs to vent for 310 days for the worst case.

Performing the same calculation for the base case yields 360 days.

From the calculations above, the waste box must be allowed to breathe 1 year after retrieval.

\subsection{DEGRADATION OF THE GASKETS}

Forty years of storage underground may have caused the gaskets to degrade resulting in additional flow paths. 
Figure 11 of the paper Effect of Contact Pressure and Thermal Degradation on the Sealability of O-ring Seals (1997) presents the results of tests that show that rubber O-ring seals (made of acrylic rubber [ACM] and acrylonitrile-butadiene rubber [NBR]) leak when the compression set exceeds $80 \%$. Other tests show that at a compression set of $80 \%$, the hardness is 87. The hardness is related to the ability of the O-ring to seal. For ACM rubber the compression set was reached in about $500 \mathrm{hrs}$ when the $\mathrm{O}$-ring was in a $150{ }^{\circ} \mathrm{C}$ environment. The conditions were reached at about $1000 \mathrm{hr}$ and $8000 \mathrm{hr}$ at $120^{\circ} \mathrm{C}$. Changes typically follow an Arrhenius equation (change is proportional to $\mathrm{Ae}^{\mathrm{kT}}$ ). This is evidenced by the fact that compression sets of $80 \%$ are seen only after 40 years in hot climates (per Natural Ageing of Rubber - Changes in Physical Properties over 40 Years (2000) - see below). These results suggest that neoprene would not harden to the point that it leaks when stored underground (temperatures less than about $\left.25^{\circ} \mathrm{C}\right)$ for 40 years $(350,600 \mathrm{hrs})$.

The paper Aging Study of Neoprene FB Uncured Rubber in Support of an Obsolescence Issue for EPDM Rubber Insulation Used in the Reusable Solid Rocket Motor of the Space Shuttle (1999) provides the results of tests on "new" and "old" Neoprene FB rubber. The "old" Neoprene was kept in cold storage at $40{ }^{\circ} \mathrm{F}$ for more than 11 years. The "new" Neoprene was kept in cold storage $\left(40^{\circ} \mathrm{F}\right)$ for 8 months. The experimental and analytical data from Section 3.4.1 of the reference showed that the gel time for continued storage at $40^{\circ} \mathrm{F}$ was 12.7 years for the "old" Neoprene and 72.6 years for the "new" Neoprene. "Gel" means initiation or visible formation of a gel or insoluble polymer fraction within the polymeric molecule. Gel formation causes a decrease in strength.

The equations are:

$$
\begin{array}{ll}
\text { "old" Neoprene } & \ln \left(\mathrm{t}_{\text {gel }}\right)=-25.79+11522 / \mathrm{T} \\
\text { "new" Neoprene } & \ln \left(\mathrm{t}_{\text {gel }}\right)=-30.82+13403 / \mathrm{T}
\end{array}
$$

where the unit of $t_{\mathrm{gel}}$ is minutes.

At $55^{\circ} \mathrm{F}$ or $286 \mathrm{~K}$ (a typical in-ground temperature) the time to $t_{\text {gel }}$ is 3.6 years for the "old" Neoprene and 17.6 years for the "new" Neoprene. This paper would suggest that gel formation had occurred in the gaskets of the waste boxes stored in the ground at Hanford.

Section 11.2.3.2 of Chapter 11 of the text Weathering of Polymers (1983) presents the results of the various tests performed on Chloroprene Rubbers (neoprene). The results of testing are:

- A general purpose neoprene compound demonstrated good retention of compression properties after 20 years of storage in the tropics.

- A compound based on neoprene retained $70 \%$ of its initial elongation after 4-year exposure in the desert. A medium soft Neoprene compound exposed in Panama for 6 years showed similar behavior. Similar results are shown for four chloroprene compounds exposed for 5 years at a range of locations.

- The properties of Neoprene subjected to soil burial dropped sharply over 10 years. A fungicide appeared to be the cause of the change in hardness. 
These results suggest that there might be some change in properties in soil burial at Hanford but not necessarily in storage in air. This result is likely dependent on the type of soil and the microbes in the soil.

The textbook Natural Ageing of Rubber - Changes in Physical Properties over 40 Years (2000) presents the results of three types of polychloroprene (Neoprene). The results are:

\begin{tabular}{|c|c|c|c|c|}
\hline \multirow[b]{2}{*}{ Compound } & \multicolumn{4}{|c|}{ Initial Value on 40-year Value of Property-Temperate Climate } \\
\hline & Hardness & Volume Change & $\begin{array}{c}\text { Rebound } \\
\text { Resilience }\end{array}$ & Tensile Strength \\
\hline $\begin{array}{l}\mathrm{L} \text { (general } \\
\text { purpose } \\
\text { polychloroprene) } \\
\text { (page } 96 \text { of the } \\
\text { reference) }\end{array}$ & $\begin{array}{c}63.8 \text { to } 67.4 \\
(5.6 \%)\end{array}$ & $\begin{array}{c}54.2 \text { to } 55.8 \\
(3 \%)\end{array}$ & $\begin{array}{c}54.1 \text { to } 58.3 \\
(7.8 \%)\end{array}$ & $\begin{array}{c}17 \text { to } 16.8 \\
(-1.2 \%)\end{array}$ \\
\hline $\begin{array}{l}\text { M (natural aged } \\
\text { polychloroprene) } \\
\text { (page } 107 \text { of the } \\
\text { reference) }\end{array}$ & $\begin{array}{c}62.7 \text { to } 72.7 \\
(16 \%)\end{array}$ & $\begin{array}{c}53.3 \text { to } 55.0 \\
(3.2 \%)\end{array}$ & $\begin{array}{c}46.3 \text { to } 52.1 \\
(13 \%)\end{array}$ & $\begin{array}{c}18.5 \text { to } 16.3 \\
(-12 \%)\end{array}$ \\
\hline $\begin{array}{l}\mathrm{N} \text { (heat aged } \\
\text { polychloroprene) } \\
\text { (page } 115 \text { of the } \\
\text { reference) }\end{array}$ & $\begin{array}{c}81.3 \text { to } 89.9 \\
(11 \%)\end{array}$ & $\begin{array}{c}42.6 \text { to } 39.1 \\
(-8.2 \%)\end{array}$ & $\begin{array}{c}23.3 \text { to } 29.1 \\
(25 \%)\end{array}$ & $\begin{array}{c}11.6 \text { to } 9.67 \\
(-16 \%)\end{array}$ \\
\hline
\end{tabular}

Of interest was the result that Compounds $\mathrm{L}$ and $\mathrm{M}$ increased in volume over time in a temperature climate (burial may be likened to a temperate climate).

The long term compression set was also measured. The underground environment at burial is assumed to be like a temperate climate. The compression set after 40 years is

\begin{tabular}{cc} 
Compound & $\begin{array}{c}\text { Long term } \\
\text { compression } \\
\text { set, \% }\end{array}$ \\
\cline { 1 - 2 } L & 59 \\
M & 79 \\
N & 81
\end{tabular}

Given the results of the paper on contact pressure (leakage when compression set exceeds $80 \%$ ), Compound $\mathrm{M}$ and $\mathrm{N}$ may leak at times greater than the 40 years of burial.

The results suggest that there is no significant change in properties over 40 years (resulting in changes that are less than those for the test conditions) in buried storage where it is cooler and there is no degradation due to components of sunlight. 
Section 4.4.2 of the report Preliminary Review of the Degradation of Cellulosic, Plastic, and Rubber Materials in the Waste Isolation Pilot Plant, and Possible Effects on Magnesium Oxide Safety Factor Calculations (2006) provides a discussion microbial attack on rubber including neoprene. The report states that there are bacteria and fungi that are capable of degrading rubber. The extent of the degradation is a function of the type of bacteria (the group or family to which it belongs), the type of rubber and the additives used in the rubber. Studies have found rubber - degrading bacteria present in WIPP during aerobic conditions. Also identified were some anaerobic microbes that would continue to degrade rubber after the oxygen is gone. The extent or effect of the degradation was not stated.

\subsection{REFERENCES}

Aging Study of Neoprene FB Uncured Rubber in Support of an Obsolescence Issue for EPDM Rubber Insulation Used in the Reusable Solid Rocket Motor of the Space Shuttle, 1999, Thermochimica Acta 357-358 (2000) 303-312, NASA/MSFC, Marshall Space Flight Center, Alabama, Alabama.

CTP 410, 1951, Flow of Fluids Through Valves, Fittings and Pipe, Crane Technical Paper 410 , Crane Company, Chicago, Illinois.

Cussler, E. L., 1997, Diffusion: Mass Transfer in Fluid Systems, Cambridge University Press, New York, New York.

DP-1604, 1982, Radiogenic Gas Accumulation in TRU Waste Storage Drums, E.I duPont de Nemours Co., Aiken, South Carolina.

Effect of Contact Pressure and Thermal Degradation on the Sealability of O-ring Seals, 1997, JSAE Review 19 (1998) 123-128, Engineering Research Department 3, Tochigi R\&D Center, Tochigi, Japan.

Estimate of Hydrogen Concentration in $K W-14,1995$, PNL-IX-IR-0006, Pacific Northwest Laboratories, Richland, Washington.

H-2-35001, 1979, Transuranic Dry Waste Burial Box Type $1 \& 2$, Rev. 7, Westinghouse Hanford Company, Richland, Washington.

H-2-72560, 1980, Transuranic Dry Waste Burial Box Type I, 3 sheets, Westinghouse Hanford Company, Richland, Washington.

H-2-74561, 1978, Transuranic Dry Waste Burial Box Type II, 3 sheets. Westinghouse Hanford Company, Richland, Washington.

H-2-74608, 1978, Transuranic Dry Waste Burial Box $8^{\prime} \times 9^{\prime} X 12^{\prime}, 3$ sheets, Westinghouse Hanford Company, Richland, Washington. 
HNF-22524, Rev. 1

H-2-74714, 1978, Transuranic Dry Waste Burial Box, 3 sheets, Westinghouse Hanford Company, Richland, Washington.

H-2-91888, 1986, 7'- $0^{\prime \prime} X 6^{\prime}-0^{\prime \prime}$ Steel Corrugated Box Assembly, Rev. 2, Westinghouse Hanford Company, Richland, Washington.

HNF-9411, 2004, Analysis of Available Hydrogen Data and Accumulation of Hydrogen in Unvented TRU Drums, Fluor Hanford, Inc., Richland, Washington.

HNF-14741, 2003, Waste Management Project Master Documented Safety Analysis, Fluor Hanford, Inc., Richland, Washington.

HNF-16166, 2007, Required Staging Times for Hydrogen Diffusion in Vented Waste Containers, Rev. 7a, Fluor Hanford, Inc., Richland, Washington.

HNF-25634, 2006, Potential for a Volatile Organic Compound (VOC) Deflagration in a TRU Drum, Rev. 0, Fluor Hanford, Inc., Richland, Washington.

INEL/EXT-98-00987, 1999, TRUPACT-II Matrix Depletion Program Final Report, Idaho National Engineering and Environmental Laboratory, Idaho Falls, Idaho.

LA-7674-MS, 1979, Gas Generation from Radiolytic Attack of TRU-Contaminated Hydrogenous Waste, Los Alamos Scientific Laboratory, Los Alamos, New Mexico.

Natural Ageing of Rubber - Changes in Physical Properties over 40 Years, 2000, Rapra Technology Limited, United Kingdom.

NUREG/CR-2726, 1983, Light Water Reactor Hydrogen Manual, Prepared by Sandia National Laboratory for the US Nuclear Regulatory Commission, Washington, D.C.

Permeability and other Film Properties of Plastics and Elastomers, 1995, William Andrews Publishing, New York, New York.

Permeability Properties of Plastics and Elastomers - A Guide to Packaging and Barrier Materials, 2003, Plastics Design Library, Norwick, New York.

PNNL-11212, 1996, Hydrogen and Oxygen Concentrations in IXCs: A Compilation, Pacific Northwest National Laboratory, Richland, Washington.

Polymer Handbook, $4^{\text {th }}$ Edition, 1999, John Wiley and Sons, New York, New York.

Preliminary Review of the Degradation of Cellulosic, Plastic, and Rubber Materials in the Waste Isolation Pilot Plant, and Possible Effects on Magnesium Oxide Safety Factor Calculations, 2006, S. Cohen \& Associates, Vienna, Virginia. 
Restrepo, L. F., 1989, Probabilistic Risk Assessment of Hydrogen Generation in Drums Containing Plutonium-Contaminated Materials, Rocky Flats Environmental Technology Site, Golden, Colorado.

Roark's Formulas for Stress and Strain, 1989, McGraw-Hill Book Company, New York, New York.

RPP-12710, Rev 1, 2003, Flammable Gas Diffusion From Waste Transfer Associated Structures, CH2MHill Hanford Group, Richland, Washington.

Weathering of Polymers, 1983, Applied Science Publishers, New York, New York.

WHC-SD-SNF-SARR-003, 1994, Hydrogen Production in the K-Basin Ion Exchange Columns, Modules, and Cartridge Filters, Westinghouse Hanford Company, Richland, Washington.

WSRC-TR-90-165, 1990, Transuranic Drum Hydrogen Explosion Tests, Westinghouse Savannah River Company, Aiken, South Carolina.

Yaws' Handbook of Thermodynamics and Physical Properties of Chemical Compounds, Chemical Engineer's Handbook, Seventh Edition, McGraw-Hill, New York, New York Knovel Internet Library. 
HNF-22524, Rev. 1

This page is intentionally left blank. 
HNF-22524, Rev. 1

APPENDIX A - LISTING OF THE WASTE BOXES 
HNF-22524, Rev. 1

This page is intentionally left blank. 
HNF-22524, Rev. 1

\section{Appendix A}

Listing of the Waste Boxes

\section{IDENTIFICATION}

(See Note 1)

M-01 (NHM)

M-02 (NHM)

M-06 (NHM)

M-10 (NHM)

M-29 (NHM)

M-40 (NHM)

3389-2-5 (NHM)

2350-3 (Poss. E)

3950-1-1 (NHM)

3950-1-2 (NHM)

CSB-7 (NHM)

3950-2-1 (NHM)

3950-3-2 (NHM)

353612-7 (NHM)

353613-14 (NHM)

CSB-9 (NHM)

353614-1 (NHM)

\section{BURIAL}

\section{GROUND TRENCH DE-CI COMPONENT}

218W4C T01

218W4C T01

218W4C T01

218W4C T01

218W4C T01

218W4C T01

218W4C T20

218W4C Z10

218W4C T20

218W4C T20

218W4C T01

218W4C T20

218W4C T20

218W4C T20

218W4C T20

218W4C T01

218W4C T20
18.7 METAL/IRON/GALVANIZED/SHEET

18.7 METAL/IRON/GALVANIZED/SHEET

18.7 METAL/IRON/GALVANIZED/SHEET

18.7 METAL/IRON/GALVANIZED/SHEET

18.7 METAL/IRON/GALVANIZED/SHEET

18.7 METAL/IRON/GALVANIZED/SHEET

11.0 METAL/IRON/GALVANIZED/SHEET PLASTIC/POLYURATHANE PAPER/CARDBOARD

GLASS

RUBBER

WOOD/LUMBER/PLYWOOD

8.6 METAL/IRON/GALVANIZED/SHEET

PLASTIC/POLYURATHANE

16.3 CONCRETE

16.0 CONCRETE

16.3 CONCRETE

16.3 CONCRETE

15.2 CONCRETE

8.1 METAL/IRON/GALVANIZED/SHEET GLASS CEMENT

$28.3 \mathrm{METAL} / \mathrm{IRON} / \mathrm{GALVANIZED/SHEET}$ GLASS

16.3 CONCRETE

$18.0 \mathrm{METAL} / \mathrm{IRON} / \mathrm{GALVANIZED/SHEET}$ 
HNF-22524, Rev. 1

IDENTIFICATION

(See Note 1)

353614-2 (NHM)

353616-1 (NHM)

3950-11-2 (NHM)

353618-1 (NHM)

353618-2 (NHM)

353619-1 (NHM)

353619-2 (NHM)

3950-10-2 (NHM)

WH82-058

$2350-6$

4242-1-1 (NHM)
BURIAL

GROUND TRENCH DE-CI COMPONENT

GLASS

218W4C T20

218W4C T20

27.3 METAL/IRON/GALVANIZED/SHEET GLASS

13.2 STAINLESS STEEL METAL/IRON/GALVANIZED/SHEET GLASS

61.2 CEMENT

$22.5 \mathrm{METAL/IRON/GALVANIZED/SHEET}$ GLASS

CEMENT

218W4C T20

32.3 METAL/IRON/GALVANIZED/SHEET GLASS

CEMENT

15.5 METAL/IRON/GALVANIZED/SHEET CEMENT

GLASS

218W4C T20

30.4 METAL/IRON/GALVANIZED/SHEET CEMENT

GLASS

218W4C T20

218W4C T07

21.3 CONCRETE

37.0 PAPER/CARDBOARD WOOD/LUMBER/PLYWOOD PLASTIC/POLYURATHANE METAL/IRON/GALVANIZED/SHEET GLASS

CONCRETE

COTTON/KOTEX

CLOTH/RAGS/NYLON

218W4C Z10

11.5 METAL/IRON/GALVANIZED/SHEET PLASTIC/POLYURATHANE CLOTH/RAGS/NYLON

$6.9 \mathrm{METAL/IRON/GALVANIZED/SHEET}$ GLASS

BRICK/FIREBRICK

CONCRETE 
HNF-22524, Rev. 1

\section{IDENTIFICATION \\ (See Note 1)}

4242-1-2 (NHM)

353617-1 (NHM)

84SB01 (Poss. E)

SB83121.A

SB84081

SB82021

SB84031

SB84118 (Poss. E)

SB8457 (Poss. E)

SB82042

SB84112 (Poss. E)
BURIAL

GROUND TRENCH DE-CI COMPONENT

218W4C Z10

218W4C T01

218W4C Z10

218W4C Z10

218W4C Z10

218W4C Z10

218W4C Z10

218W4C Z10

218W4C Z10

218W4C Z10

218W4C Z10
12.4 METAL/IRON/GALVANIZED/SHEET GLASS

BRICK/FIREBRICK

CONCRETE

$31.4 \mathrm{METAL} / \mathrm{IRON} / \mathrm{GALVANIZED/SHEET}$ GLASS

CEMENT

16.0 METAL/IRON/GALVANIZED/SHEET PAPER/CARDBOARD

20.0 STAINLESS STEEL METAL/IRON/GALVANIZED/SHEET GLASS WOOD/LUMBER/PLYWOOD PLASTIC/POLYURATHANE

25.4 METAL/IRON/GALVANIZED/SHEET FILTERS

PLEXIGLASS

WOOD/LUMBER/PLYWOOD

PLASTIC/POLYURATHANE

43.2 METAL/IRON/GALVANIZED/SHEET WOOD/LUMBER/PLYWOOD PLASTIC/POLYURATHANE

18.1 METAL/IRON/GALVANIZED/SHEET PLEXIGLASS

PLASTIC/POLYURATHANE

9.9 STAINLESS STEEL PLASTIC/POLYURATHANE

20.8 STAINLESS STEEL METAL/IRON/GALVANIZED/SHEET PLASTIC/POLYURATHANE

12.9 STAINLESS STEEL METAL/IRON/GALVANIZED/SHEET PLASTIC/POLYURATHANE WOOD/LUMBER/PLYWOOD PAPER/CARDBOARD

40.2 STAINLESS STEEL PLEXIGLASS 
HNF-22524, Rev. 1

IDENTIFICATION

(See Note 1)

SB84032

SB83121.B

SB85021

SB85011

SB-85083

SB-85084

RHA84SB03

RHA84SB05

SB85-06-1

SB85-06-2
BURIAL

\section{GROUND TRENCH DE-CI COMPONENT}

PLASTIC/POLYURATHANE

218W4C Z10

218W4C T07

218W4C Z10

21.3 METAL/IRON/GALVANIZED/SHEET PLASTIC/POLYURATHANE PAPER/CARDBOARD CLOTH/RAGS/NYLON

20.6 METAL/IRON/GALVANIZED/SHEET GLASS

RUBBER

57.3 STAINLESS STEEL

GLASS

PAPER/CARDBOARD

PLASTIC/POLYURATHANE

218W4C T07

218W4C S24 PLASTIC/POLYURATHANE CLOTH/RAGS/NYLON

8.1 METAL/IRON/GALVANIZED/SHEET WOOD/LUMBER/PLYWOOD PLASTIC/POLYURATHANE

16.0 FILTERS METAL/IRON/GALVANIZED/SHEET

47.8 METAL/IRON/GALVANIZED/SHEET PLASTIC/POLYURATHANE FILTERS ALUMINUM 
HNF-22524, Rev. 1

\section{IDENTIFICATION \\ (See Note 1)}

SB-85032

SB-8503-1 (Poss. E)

PNL186022

PNL186024

PNL186025

PNL186026

\section{BURIAL}

GROUND TRENCH DE-CI COMPONENT

218W4C T07

218W4C T07

218W4C S24

218W4C S24

218W4C S24

218W4C S24
35.7 PAPER/CARDBOARD

PLASTIC/POLYURATHANE

CLOTH/RAGS/NYLON

RUBBER

PLEXIGLASS

FOAM/STYROFOAM/PYROFOAM

FIBERGLASS

GLASS

METAL/IRON/GALVANIZED/SHEET

50.7 STAINLESS STEEL

PLASTIC/POLYURATHANE

APER/CARDBOARD

METAL/IRON/GALVANIZED/SHEET

PLASTIC/POLYURATHANE

CLOTH/RAGS/NYLON

PLEXIGLASS

WOOD/LUMBER/PLYWOOD

METAL/IRON/GALVANIZED/SHEET

BRASS METAL

34.5 PAPER/CARDBOARD

PLASTIC/POLYURATHANE

FOAM/STYROFOAM/PYROFOAM

FIBERGLASS

WOOD/LUMBER/PLYWOOD

METAL/IRON/GALVANIZED/SHEET

40.0 PAPER/CARDBOARD

PLASTIC/POLYURATHANE

CLOTH/RAGS/NYLON

RUBBER

PLEXIGLASS

METAL/IRON/GALVANIZED/SHEET 
HNF-22524, Rev. 1

IDENTIFICATION

(See Note 1)

PNL186027
BURIAL

\section{GROUND TRENCH DE-CI COMPONENT}

218W4C S24

\author{
41.3 PAPER/CARDBOARD \\ PLASTIC/POLYURATHANE \\ CLOTH/RAGS/NYLON \\ RUBBER \\ FIBERGLASS \\ PLEXIGLASS \\ WOOD/LUMBER/PLYWOOD \\ METAL/IRON/GALVANIZED/SHEET
}

Note 1: $N H M$ means no hydrogenous material, like rags, paper, plastics, etc. While concrete has some water in it, it is much less of a hydrogen source than are the other materials.

Poss. $E$ means possible equipment. This waste could have the radioactive material far from the material that can degrade radiolytically. 
HNF-22524, Rev. 1

APPENDIX B - THE EFFECT OF A HYDROGEN
DEFLAGRATION ON THE WASTE BOX

B-1 
HNF-22524, Rev. 1

This page is intentionally left blank.

B-2 


\section{Appendix B}

\section{The Effect of a Hydrogen Deflagration on the Waste Box}

A deflagration results in a rapid pressurization of the waste box. This causes stress on the lid and sides. The ability of a waste box to withstand a deflagration is found below.

EPRI NP-3878, Large-Scale Hydrogen Combustion Experiments, provided results of hydrogen deflagration in vessels. The AECL vessel was an $8 \mathrm{ft}$ diameter sphere. The FITS vessel was a vertical cylinder $11.2 \mathrm{ft}$ long and $4.9 \mathrm{ft}$ in diameter. The LLNL vessel was a horizontal cylinder $1.7 \mathrm{ft}$ in diameter and $5 \mathrm{ft}$ long. The peak pressures at $7 \%$ hydrogen (and the figures from the reference from which the data comes) were
Fig 4-14
AECL
$2.3 \operatorname{atm}(34 \mathrm{psia})$
Fig 4-15 FITS
$2.3 \operatorname{atm}(34$ psia $)$
Fig 4-17
LLNL
$1.3 \operatorname{atm}(19$ psia $)$

The theoretical adiabatic, constant volume combustion pressure at $7 \%$ hydrogen in air is $3.2 \mathrm{~atm}$ from NUREG/CR-2726, Light Water Reactor Hydrogen Manual (1983). A value of $2.5 \mathrm{~atm}$ or 36.7 psia (22 psig) will be used in the analysis as it bounds the test data.

The pressure on the lid will be found using static analyses. The lid is modeled as a flat plate.

The standard waste box certified by WIPP is a rectangular box having rounded ends. The box is 52 inches wide, 69 inches from rounded end to rounded end. The distance between the start of the rounded portions is 45 inches. The box will be modeled as a rectangular box 52 inches wide and 62 inches long. The box is 36 inches tall. The sides, base and lid are 10 gauge steel $(0.135$ in thick).

Roark's Formulas for Stress and Strain, Table 26, Case 8 provides the stress in a rectangular flat plate with clamped edges. The equation for maximum stress is:

$$
\sigma_{\max }=\frac{\beta q b^{2}}{t^{2}}
$$

Where $\beta=0.38$ for a rectangle 62 in by 52 in

$\mathrm{q}=$ pressure on the lid, psig

$\mathrm{b}=$ short distance, in.

$=52$ in

$\mathrm{t}=$ plate thickness, in

$=0.375 \mathrm{in}$.

$\sigma_{\max }=$ maximum stress in the plate 
The pressure in a dynamic situation such as a deflagration is equal to the static pressure times the dynamic load factor (DLF). The dynamic load factor is the ratio distance a single degree-offreedom oscillation under dynamic conditions to the distance traveled under static loss. The DLF is given in Figure 2.8, of Section $2.3 \mathrm{c}$ of Structural Dynamics. The loading is assumed to be triangular. The peak force (corresponding to $22 \mathrm{psig}$ ) occurs at $t_{d} / 2$. At this point it is assumed that the gaskets blow out (peak force based on $22 \mathrm{psig}$ ) and the box depressurizes. The time to peak pressure is found from Figure 4-18 of the EPRI report. The values are $6 \mathrm{~s}$ for the AECL sphere and $4 \mathrm{~s}$ for the VGES cylinder. The ignition point in both cases was at the bottom. Dividing the length of the vessels by the time to peak pressure yields the flame speeds. The flame speeds were found to be about 0.5 to $1 \mathrm{~m} / \mathrm{s}$.

In the case considered here the average length is 57 in or $1.45 \mathrm{~m}$. Using a flame speed of $1 \mathrm{~m} / \mathrm{s}$, the value of $0.5 \mathrm{t}_{\mathrm{d}}$ is $1.45 \mathrm{~s}$.

Therefore, $\mathrm{t}_{\mathrm{d}}=2.9 \mathrm{~s}$.

The other input needed to obtain DLF is the natural period of the lid. The natural period (T) is related to the frequency (f) by

$$
\mathbf{f}=\frac{2 \pi}{T}
$$

Roark's Formula for Stress and Strain, Table 36, Case 15 gives the natural frequency for a clamped rectangular plate

$$
\mathrm{f}=\frac{K}{2 \pi}\left(\frac{D g}{q b^{4}}\right)^{0.5}
$$

Where $\mathrm{K}=31$ for a plate $62 \mathrm{in}$. long by $52 \mathrm{in}$. wide (ratio is 0.84 )

$$
\begin{aligned}
\mathrm{D} & =\mathrm{Et}^{3} / 12\left(1-\mathrm{v}^{2}\right)=135,200 \mathrm{lbf}-\mathrm{in} \\
\mathrm{E} & =\text { modulus of elasticity }=28 \times 10^{6} \mathrm{psi} \\
\mathrm{t} & =\text { lid thickness, in } . \\
& =0.375 \mathrm{in} . \\
\mathrm{v} & =\text { Poisson's ratio }=0.3 \\
\mathrm{q} & =22 \mathrm{psi} \\
\mathrm{g} & =\text { acceleration due to gravity, in } / \mathrm{s}^{2} \\
& =386 \mathrm{in} / \mathrm{s}^{2} \\
\mathrm{~g}, \mathrm{~b} & =\text { defined above }
\end{aligned}
$$

Solving for " $\mathrm{f}$ " yields 2.8. Therefore, using equation (2), " $\mathrm{T}$ " is 2.24 and " $\mathrm{t}_{\mathrm{d}} / \mathrm{T}$ " is 1.3 . Figure 2.8 of Structural Dynamics (pg 47) shows that for $t_{d} / T$ of 1.3 , the DLF is 1.35 . Using a DLF of 1.35 the value of " $q$ " in the stress equation (Equation 1) becomes

$$
\mathrm{q}=(22 \mathrm{psig})(1.35)=30 \mathrm{psig}
$$


HNF-22524, Rev. 1

Solving for the stress in the plate, " $\sigma$ ", using equation (1), yields $2.2 \times 10^{5}$ psi. This stress exceeds the ultimate stress for steel of 60,000 psi to 75,000 psi from Table 38 of Roark's Formula for Stress and Strain. Therefore, the lid fails. 
HNF-22524, Rev. 1

This page is intentionally left blank.

B-6 
HNF-22524, Rev. 1

APPENDIX C - TECHNICAL PEER REVIEW SHEET 
HNF-22524, Rev. 1

This page is intentionally left blank. 


\section{Checklist For Technical Peer Review}

\begin{tabular}{|c|c|c|c|c|}
\hline \multicolumn{5}{|c|}{ Document Reviewed: HNF-22524 Revision 1} \\
\hline & \multicolumn{4}{|c|}{ Title: Hydrogen and VOC Retention in Waste Boxes } \\
\hline & \multicolumn{4}{|c|}{ Author: R. M. Marusich } \\
\hline & \multicolumn{4}{|c|}{ Date: June 2008} \\
\hline & \multicolumn{2}{|c|}{ Scope of Review: } & \multicolumn{2}{|r|}{ Reviewed Sections 4.8.1, 4.8.2, and 4.9. } \\
\hline Yes & $\mathrm{No}^{*}$ & $N A$ & & \\
\hline$[x]$ & 1 & l & & Referenced analyses appropriate. \\
\hline$[\alpha]$ & 11 & 1 & & Problem completely defined and all potential configurations considered. \\
\hline 11 & {$[1$} & $\Delta 1$ & & An approved formal approach was used to devclop the accident scenarios \\
\hline l & $1 \quad 1$ & {$[A]$} & & Accident scenarios developed in a clear and logical manner. \\
\hline$[\alpha]$ & ] & [ ] & & Necessary assumptions explicitly stated and supported. \\
\hline [ $]$ & [ ] & {$[A]$} & & Computer codes and data files documented. \\
\hline$[\alpha]$ & {[} & [ ] & & Data used in calculations explicitly stated in document. \\
\hline$[x]$ & [ ] & L & & Data checked for consistency with original source information as applicable. \\
\hline$\infty 1$ & $1]$ & 1 & & Mathematical derivations checked including dimensional consistency of results. \\
\hline$[\alpha]$ & 11 & 11 & & $\begin{array}{l}\text { Models appropriate and used within range of validity, or use oulside range of } \\
\text { established validity justified. }\end{array}$ \\
\hline $\mathscr{x}]$ & [ ] & [ ] & & $\begin{array}{l}\text { Hand calculations checked for errors. Spreadsheet results should be treatcd cxactly } \\
\text { the same as hand calculations. }\end{array}$ \\
\hline 11 & 11 & {$[x]$} & & Software input correct and consistent with document reviewed. \\
\hline 1 & l ] & $|x|$ & & $\begin{array}{l}\text { Software output consistent with input and with results reported in document } \\
\text { rcvicwed. }\end{array}$ \\
\hline [ ] & [ ] & {$[x]$} & & $\begin{array}{l}\text { Limits/criteria/guidelines applied to analysis results are appropriatc and rcfcrenced. } \\
\text { Limits/criteria/guidelines checked against references. }\end{array}$ \\
\hline$[\not \alpha]$ & [ 1 & 1 & & Safety margins consistent with good engineering practices. \\
\hline$[x]$ & [ ] & 1 & & Conclusions consistent with analytical results and applicable limits. \\
\hline$[x]$ & [ ] & ] & & Results and conclusions address all points required in the problem statement. \\
\hline$[x]$ & 1 & {[} & & Format consistent with applicablc guides or other standards. \\
\hline 1 & ] & {$[\alpha]$} & *** & Review calculations, comments, and/or notes are attached. \\
\hline$\left[X^{]}\right]$ & [ ] & [ ] & & $\begin{array}{l}\text { Document approved (for example, the reviewer affirms the technical accuracy of the } \\
\text { document). }\end{array}$ \\
\hline $\begin{array}{ll}* & \mathrm{~A} \\
\mathrm{~A} & \mathrm{~A} \\
\mathrm{ch} & \mathrm{ch}\end{array}$ & \multicolumn{4}{|c|}{$\begin{array}{l}\text { All "no" responses must be explained on an additional sheet. } \\
\text { Any calculations, comments, or notes generated as part of this review should be signed, dated and attached to this } \\
\text { checklist. The material should be labeled and recorded in such a manner as to be understandable to a technically } \\
\text { qualified third party. }\end{array}$} \\
\hline
\end{tabular}


HNF-22524, Rev. 1

This page is intentionally left blank. 